Check for updates

Cite this: RSC Adv., 2018, 8, 41795

Received 25th August 2018

Accepted 24th September 2018

DOI: $10.1039 / \mathrm{c} 8 \mathrm{ra0} 07100 \mathrm{~d}$

rsc.li/rsc-advances

\section{Molecular design and synthesis of new dithiocarbazate complexes; crystal structure, bioactivities and nano studies $\uparrow$}

\begin{abstract}
Zahra Yekke-ghasemi, ${ }^{a}$ Reza Takjoo, (D) *a Mohammad Ramezani ${ }^{\mathrm{b}}$ and Joel T. Mague
The syntheses of a new set of metal complexes $\mathrm{MoO}_{2} \mathrm{~L}^{\prime}\left(\mathrm{CH}_{3} \mathrm{OH}\right), \mathrm{VOL}^{\prime}\left(\mathrm{CH}_{3} \mathrm{O}\right)\left(\mathrm{CH}_{3} \mathrm{OH}\right), \mathrm{MnL}_{2}^{\prime}, \mathrm{SnL}_{2}^{\prime}, \mathrm{SnL}^{\prime} \mathrm{Cl}_{2}$ and $\mathrm{SnL}^{\prime} \mathrm{I}_{2}$ with a new ligand $\left(\mathrm{L}=\left(2, \mathrm{2}^{\prime}\right.\right.$ (disulfanediylbis((ethylthio)methylene)bis(hydrazin-2-yl-1-ylidene) bis(methanylylidene)) diphenol; $L^{\prime}=$ S-ethyl-3-(2-hydroxyphenyl)methylenedithiocarbazate are described along with characterization by elemental analysis, mass spectrometry, spectroscopic $\left(\mathrm{IR},{ }^{1} \mathrm{H}-\right.$ and ${ }^{13} \mathrm{C}$ NMR) and TGA techniques. The crystal structures of compounds were determined by single crystal $X$-ray diffraction analysis and compared to powder X-ray diffraction (PXRD) patterns of the nano complexes obtained using ultrasonic methods. The PXRD results indicate that the compounds synthesized by ultrasonic methods have high crystallinity. The compounds were evaluated in an in vitro cytotoxicity study with two human cancer cell lines. The results of this study revealed that all complexes exhibit good cytotoxic activity when compared to the clinical drug, cisplatin. Interaction of the samples with human serum albumin (HSA) was investigated using fluorescence spectrophotometric methods and the SternVolmer quenching constant $\left(K_{\mathrm{SV}}\right)$ and free energy changes $(\Delta G)$ were calculated at $298 \mathrm{~K}$. The fluorescence quenching method is used to determine the number of binding sites $(n)$ and association constants $\left(K_{\mathrm{a}}\right)$ at the same temperatures.
\end{abstract}

\section{Introduction}

$S$-Alkyl/aryl dithiocarbazates as sulfur-nitrogen chelating agents are interesting in the context of coordination chemistry. Owing to hard nitrogen and soft sulfur donor atoms, formation of five-membered chelate rings can stabilize transition and nontransition metals in various oxidation states. ${ }^{1,2}$ Through reacting various aldehydes and ketones with dithiocarbazates multidentate ligands will form for which, depending on the different structures obtained upon coordination with metal ions, different biological applications including antibacterial, antifungal and anticancer activity could be obtained. ${ }^{3} \mathrm{~A}$ variety of coordination complexes and cytotoxic compounds have been investigated for the treatment of human cancer in recent years ${ }^{4,5}$ with cisplatin as the most widely used drug but its use is limited in medicine due to the side effects such as nephrotoxicity and drug resistance. ${ }^{6,7}$ Other studies have suggested that

\footnotetext{
${ }^{a}$ Department of Chemistry, Faculty of Science, Ferdowsi University of Mashhad, Mashhad, Iran.E-mail: r.takjoo@um.ac.ir; rezatakjoo@yahoo.com; Tel: +98 513 8805536

${ }^{b}$ Pharmaceutical Research Center, School of Pharmacy, Mashhad University of Medical Sciences, Mashhad, Iran

'Department of Chemistry, Tulane University, New Orleans, LA 70118, USA

$\dagger$ Electronic supplementary information (ESI) available: CCDC 1851305-1851311 contains the supplementary crystallographic data for L and $\mathbf{1}$ to $\mathbf{6}$. For ESI and crystallographic data in CIF or other electronic format see DOI: 10.1039/c8ra07100d
}

dithiocarbazates, due to the sulfur-nitrogen chelating functionality, can reduce these side effects. ${ }^{8}$ Thus complexation of tridentate ONS-chelating derivatives of dithiocarbazates with metals such as $\mathrm{Mn},{ }^{9} \mathrm{Sn},{ }^{10} \mathrm{~V}^{11}$ and $\mathrm{Mo}^{12}$ should be interesting in chemotherapeutics especially with regard to antitumor effects. ${ }^{13}$ These metals are also known to accelerate drug action and play major roles in biological systems. For example, vanadium is present in the two enzymes of haloperoxidase and nitrogenase and also plays a role in the regulation of phosphate metabolism. ${ }^{14}$ Manganese exists at the catalytic center of the three enzymes manganese catalase, ribonucleotide reductase of certain bacteria and the photosystem II of green plants to facilitate the metabolism of the $\mathrm{O}_{2}{ }^{n-}$ unit $^{15}$ and molybdenum is at the active sites of molybdoenzymes. ${ }^{16}$

Investigation of protein-ligand interactions helps us to understand the antitumor effects of metal complexes. ${ }^{17,18}$ Albumins as a major transporter of the proteins in blood plasma are good candidates for studying these interactions. ${ }^{19}$ HSA is responsible for carrying substances in the blood and is also able to carry pharmaceutical compounds with different chemical structures. ${ }^{20}$ Six linkages are identified for ligand binding on HSA. ${ }^{21,22}$ From these six sites, two major sites are responsible for binding with metals ${ }^{23}$ with the linkage being either covalent or non-covalent. ${ }^{24}$ In general, evaluation of drug-protein interaction in order to achieve optimal therapeutic dose and the awareness of drug-protein binding capacity is essential. ${ }^{25}$ 
Therefore, in the present article, the new complexes of dithiocarbazates are designed, synthesized and characterized in order to examine their antitumor properties. The cytotoxic test of the compounds using MTT assay was performed against the Hela and MCF-7 cells. Also, the effects of dithiocarbazates in the presence of different metal ions on HSA are studied from a molecular point of view.

\section{Experimental}

\subsection{Materials and methods}

Human serum albumin (HSA 99\%, fatty acid free) was purchased from Sigma Chemical Company and RPMI-1640 medium and fetal bovine serum (FBS) from GIBCO (Gaithersburg, USA). Penicillin and streptomycin were purchased from Biochrom AG (Berlin, Germany).

All other material and solvents were purchased and used without purification. IR spectra in the region $600-4000 \mathrm{~cm}^{-1}$ were recorded with a Buck 500 Scientific. Elemental analyses (CHNS) were performed with a Thermo Finnigan Flash 1112EA elemental analyzer. The EI-mass spectra were carried out using a Varian $\mathrm{CH}-7$ instrument at $70 \mathrm{eV}$. Melting points were determined with an electrothermal digital melting point apparatus. ${ }^{1} \mathrm{H}$ and ${ }^{13} \mathrm{C}$ NMR spectra of compounds were recorded on a Bruker FUM-300 spectrometer using DMSO- $d_{6}$ as solvent. TG analysis was performed with a TGA-50 SHIMADZU instrument at a heating rate of $10{ }^{\circ} \mathrm{C} \mathrm{min}^{-1}$ under air atmosphere from ambient temperature to $950^{\circ} \mathrm{C}$. X-ray powder diffraction (XRD) measurements were recorded on a Philips diffractometer manufactured by X'pert with graphite monochromatized $\mathrm{Cu}-\mathrm{K} \alpha$ radiation. Simulated XRD powder patterns were calculated by using MERCURY based on the single crystal data. The size and morphology of nanoparticles of CP have been studied by SEM, a Leo 1450 VP, Germany.

\subsection{Synthesis of $\left(2,2^{\prime}\right.$-(disulfanediylbis((ethylthio)methylene))} bis(hydrazin-2-yl-1-ylidene)bis(methanylylidene))diphenol (L)

Carbon disulfide $(7.75 \mathrm{~g}, 102 \mathrm{mmol})$ was added dropwise to a solution of hydrazine hydrate $(5.00 \mathrm{~g}, 100 \mathrm{mmol})$, potassium hydroxide $(6.00 \mathrm{~g}, 107 \mathrm{mmol})$, water $(6 \mathrm{~mL})$ and $25 \mathrm{~mL}$ of ethanol with stirring and cooling in an ice-salt bath for one hour. Ethyl bromide $(10.35 \mathrm{~g}, 94.98 \mathrm{mmol})$ was added to the above mixture over 30 minutes. The reaction mixture was heated for 30 minutes to $25^{\circ} \mathrm{C}$ and then cooled down to $10^{\circ} \mathrm{C}$. Cold distilled water $(60 \mathrm{~mL})$ was added to the above solution and a two-phase mixture was obtained. Salicylaldehyde (5.20 g, $24.58 \mathrm{mmol}$ ) solution in $30 \mathrm{~mL}$ of $75 \%$ ethanol, at room temperature, was added to the separated organic phase. The resulting yellow precipitate was filtered off, washed with water and dried in a vacuum desiccator over silica gel.

Colorless column-like crystals were obtained after recrystallization from ethanol, yield: $5.79 \mathrm{~g}, 14.5 \%$ (based on the mass of the oily organic phase), mp: $151^{\circ} \mathrm{C}$. Anal. calc. for $\mathrm{C}_{20} \mathrm{H}_{22} \mathrm{~N}_{4} \mathrm{O}_{2} \mathrm{~S}_{4}$ (478.67 $\mathrm{g} \mathrm{mol}^{-1}$ ): C, 49.98; H, 5.03; N, 11.66; S, 26.68. Found: C, 50.07; H, 5.10; N, 11.36; S, 27.30\%. IR (KBr), $\mathrm{cm}^{-1}: \nu(\mathrm{OH}) 3108 \mathrm{~s}$, $\nu(\mathrm{C}=\mathrm{N}) 1612 \mathrm{~s}, \nu(\mathrm{N}-\mathrm{CSS}) 1526 \mathrm{~m}, \nu(\mathrm{C}-\mathrm{O}) 1262 \mathrm{~m}, \nu(\mathrm{N}-\mathrm{N}) 1028 \mathrm{~s}$.
Mass spectrometry, $m / z(\%): 239(100)\left\{\mathrm{M} / 2=\mathrm{L}^{\prime}\right\}$. ${ }^{1} \mathrm{H}$-NMR (300 MHz, DMSO- $\left.d_{6}, 295 \mathrm{~K}\right) \delta: 1.298\left(\mathrm{t}, 3 \mathrm{H}, J=7.35 \mathrm{~Hz}, \mathrm{CH}_{3}\right), 3.202$ $\left(\mathrm{q}, 2 \mathrm{H}, J=7.35 \mathrm{~Hz}, \mathrm{CH}_{2}\right), 6.919(\mathrm{~m}, 2 \mathrm{H}, \mathrm{H}-3$ and $\mathrm{H}-5), 7.316(\mathrm{td}, J$ $=7.80 \mathrm{~Hz}, 1 \mathrm{H}, \mathrm{H}-4), 7.669(\mathrm{dd}, J=7.77,1.69 \mathrm{~Hz}, 1 \mathrm{H}, \mathrm{H}-2)$, $10.259(\mathrm{~s}, 1 \mathrm{H}, \mathrm{H}-7) .{ }^{13} \mathrm{C}-\mathrm{NMR}\left(75.6 \mathrm{MHz}, \mathrm{DMSO}-d_{6}, 296 \mathrm{~K}\right)$ $\delta$ ppm: 14.37 (C10); 27.88 (C9); 127.87 (C1); 120.08 (C2); 132.65 (C3); 116.86 (C4); 157.70 (C5); 119.52 (C6); 145.15 (C7); 196.59 (C8).

\subsection{Synthesis of the metal complexes}

2.3.1. Synthesis of methanol-(2-[([(methylsulfanyl)(sulfido) methylidene]hydrazinylidene)methyl]phenolato)-dioxido-molybdenum(vi) (1). $\mathrm{MoO}_{2}(\mathrm{acac})_{2}(0.048 \mathrm{~g}, 0.195 \mathrm{mmol})$ was dissolved in dry methanol $(3 \mathrm{~mL})$ and added to solution of $\mathrm{L}(0.050 \mathrm{~g}$, $0.200 \mathrm{mmol})$ in the same solvent $(3 \mathrm{~mL})$. The mixture was stirred for 3 hours and then left to stand for 2 days whereupon the crystalline product which formed was filtered off and dried in a desiccator over anhydrous silica gel. Suitable crystals for X-ray analysis were obtained by diffusion of $n$-hexane into a methanolic solution of the complex.

Orange block-like crystal, yield: $0.1 \mathrm{~g}, 68 \%$ (based on the metal salt). Mp: $230{ }^{\circ} \mathrm{C}$. Anal. calc. for $\mathrm{C}_{11} \mathrm{H}_{14} \mathrm{MoN}_{2} \mathrm{O}_{4} \mathrm{~S}_{2}$ (398.32 $\mathrm{g} \mathrm{mol}^{-1}$ ): C, 33.17; H, 3.54; N, 7.03; S, 16.10. Found: C, $32.00 ; \mathrm{H}, 3.42 ; \mathrm{N}, 6.76 ; \mathrm{S}, 15.93 \%$. IR (KBr), $\mathrm{cm}^{-1}: \nu(\mathrm{OH}) 3418 \mathrm{w}$, $\nu(\mathrm{C}=\mathrm{N}) 1592 \mathrm{~s}, \nu(\mathrm{C}-\mathrm{O}) 1548 \mathrm{~m}, \nu(\mathrm{N}-\mathrm{N}) 1012 \mathrm{~s}$. Mass spectrom-

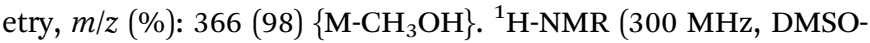
$\left.d_{6}\right) \delta: 1.356\left(\mathrm{t}, 3 \mathrm{H}, J=7.31 \mathrm{~Hz}, \mathrm{CH}_{3}\right), 3.180\left(\mathrm{~m}, 3 \mathrm{H}, \mathrm{OCH}_{3}\right), 4.131$ $\left(\mathrm{q}, 2 \mathrm{H}, J=5.24 \mathrm{~Hz}, \mathrm{CH}_{2}\right), 6.970(\mathrm{~d}, 1 \mathrm{H}, J=8.27 \mathrm{~Hz}, \mathrm{H}-2), 7.086$ $(\mathrm{m}, 1 \mathrm{H}, \mathrm{H}-4), 7.575(\mathrm{~m}, 1 \mathrm{H}, \mathrm{H}-3), 7.789(\mathrm{dd}, 1 \mathrm{H}, J=1.75$ and $7.86 \mathrm{~Hz}, \mathrm{H}-5), 8.957$ (S, $1 \mathrm{H}, \mathrm{H}-7) .{ }^{13} \mathrm{C}-\mathrm{NMR}\left(75.6 \mathrm{MHz}\right.$, DMSO- $d_{6}$, $296 \mathrm{~K}) \delta$ ppm: 15.04 (C10); 28.27 (C9); 49.08 (C11); 136.21 (C1); 120.14 (C2); 135.68 (C3); 118.84 (C4); 121.77 (C5); 171.00 (C6); $160.15(\mathrm{C} 7)$.

2.3.2. Synthesis of methoxy-methanol-oxido-(2-((thio-phenyl)methylene)hydrazono)methyl)phenolato)-vanadium(v) (2). $3 \mathrm{~mL}$ of a methanol solution of $\mathrm{VO}(\mathrm{acac})_{2}(0.022 \mathrm{~g}, 0.082$ $\mathrm{mmol})$ was added to $\mathrm{L}(0.020 \mathrm{~g}, 0.083 \mathrm{mmol})$ in $3 \mathrm{~mL}$ of the same solvent. The mixture was refluxed for $2 \mathrm{~h}$ at $70{ }^{\circ} \mathrm{C}$ on a water bath. The resulting solution was kept in a refrigerator for 2 days to generate crystals of the complex which were filtered off and dried in a desiccator over silica gel.

Dark yellow-brown thick plate-like crystal, yield: $0.1 \mathrm{~g}, 67 \%$ (based on the metal salt). Mp: $83{ }^{\circ} \mathrm{C}$. Anal. calc. for $\mathrm{C}_{12} \mathrm{H}_{17} \mathrm{~N}_{2} \mathrm{O}_{4} \mathrm{~S}_{2} \mathrm{~V}\left(368.34 \mathrm{~g} \mathrm{~mol}^{-1}\right)$ : C, 39.13; H, 4.65; N, 7.61; $\mathrm{S}$, 17.41. Found: C, 39.29; H, 3.84; N, 8.20; S, 19.75\%. IR $(\mathrm{KBr}), \mathrm{cm}^{-1}: \nu(\mathrm{OH}) 3425 \mathrm{w}, \nu(\mathrm{C}=\mathrm{N}) 1596 \mathrm{~s}, \nu(\mathrm{C}-\mathrm{O}) 1543 \mathrm{~m}, \nu(\mathrm{N}-$ N) $1028 \mathrm{~s}$. Mass spectrometry, $m / z(\%): 336(54)\left\{\mathrm{M}^{-\mathrm{CH}_{3} \mathrm{OH}}\right.$.

2.3.3. Synthesis of bis-(S-ethyl-3-(2-hydroxyphenyl)methylenedithiocarbazato)manganese(rv) (3). $3 \mathrm{~mL}$ of a methanol solution of $\mathrm{L}(0.020 \mathrm{~g}, 0.083 \mathrm{mmol})$ was added to $\mathrm{Mn}(\mathrm{OAc})_{2^{-}}$ $\cdot 4 \mathrm{H}_{2} \mathrm{O}(0.010 \mathrm{~g}, 0.041 \mathrm{mmol})$ in the same solvent $(3 \mathrm{~mL})$. The mixture was refluxed for $4 \mathrm{~h}$ at $70{ }^{\circ} \mathrm{C}$ on a water bath and the resulting dark precipitate was filtered off and dried in a desiccator over silica gel. Crystals suitable for X-ray crystallography were obtained by diffusion of $n$-hexane into a solution of the crude product in methanol. 
Intense green plate-like crystals, yield: $0.030 \mathrm{~g}, 67 \%$ (based on the metal salt). Mp: $182{ }^{\circ} \mathrm{C}$. Anal. calc. for $\mathrm{C}_{20} \mathrm{H}_{20} \mathrm{MnN}_{4} \mathrm{O}_{2} \mathrm{~S}_{4}$ (530.98 $\mathrm{g} \mathrm{mol}^{-1}$ ): C, 45.19; H, 3.97; N, 10.54; S, 24.12. Found: C, $46.33 ; \mathrm{H}, 4.00 ; \mathrm{N}, 10.43 ; \mathrm{S}, 27.14 \%$. IR $(\mathrm{KBr}), \mathrm{cm}^{-1}: \nu(\mathrm{C}=\mathrm{N})$ $1596 \mathrm{~s}, \nu(\mathrm{C}-\mathrm{O}) 1572 \mathrm{~m}, \nu(\mathrm{N}-\mathrm{N}) 1015 \mathrm{~s}$, mass spectrometry, $\mathrm{m} / \mathrm{z}$ $(\%): 530(<1)\{\mathrm{M}\}$.

2.3.4. Synthesis of bis-(2-hydroxyphenyl-S-ethyldithiocarbazato- $N, O, S)$-tin(Iv) (4). A solution of $\mathrm{SnI}_{4}(0.050 \mathrm{~g}$, $0.080 \mathrm{mmol}$ ) in $3 \mathrm{~mL}$ of absolute ethanol was added to the $\mathrm{L}$ ligand $(0.040 \mathrm{~g}, 0.166 \mathrm{mmol})$ in $3 \mathrm{~mL}$ of the same solvent. The mixture was refluxed for $1.5 \mathrm{~h}$ at $80^{\circ} \mathrm{C}$ on a water bath. Suitable crystals were obtained from slow evaporation of solvent in a refrigerator within one day.

Light yellow plate-like crystals, Yield: $0.1 \mathrm{~g}, 85 \%$ (based on metal salt). Mp: $255^{\circ} \mathrm{C}$. Anal. calc. for $\mathrm{C}_{20} \mathrm{H}_{20} \mathrm{~N}_{4} \mathrm{O}_{2} \mathrm{~S}_{4} \mathrm{Sn}(595.36 \mathrm{~g}$ $\mathrm{mol}^{-1}$ ): C, 40.35; H, 3.39; N, 9.41; S, 21.54. Found: C, 40.10; H, 3.43; N, 9.49; S, 22.37\%. IR (KBr), $\mathrm{cm}^{-1}: \nu(\mathrm{C}=\mathrm{N}) 1604 \mathrm{~s}, \nu(\mathrm{C}=\mathrm{C})$ $1464 \mathrm{~s}, \nu(\mathrm{C}-\mathrm{O}) 1284 \mathrm{~m}, \nu(\mathrm{N}-\mathrm{N}) 968 \mathrm{~s}$. Mass spectrometry, $\mathrm{m} / \mathrm{z}$ (\%): $595(<1)\{\mathrm{M}\} .{ }^{1} \mathrm{HNMR}\left(300 \mathrm{MHz}, \mathrm{DMSO}-d_{6}\right) \delta \mathrm{ppm}: 1.344(\mathrm{t}$, $\left.3 \mathrm{H}, J=7.32 \mathrm{~Hz}, \mathrm{CH}_{3}\right), 3.217$ (q, $\left.2 \mathrm{H}, J=7.31 \mathrm{~Hz}, \mathrm{CH}_{2}\right), 6.740$ (d, 1H, H-2), 6.928 (m, 1H, H-4), 7.473 (m, 1H, H-3), 7.665 (dd, 1H, J $=1.76$ and $8.01 \mathrm{~Hz}, \mathrm{H}-5), 9.306(\mathrm{~S}, 1 \mathrm{H}, \mathrm{H}-7) .{ }^{13} \mathrm{C}-\mathrm{NMR}(75.6$ MHz, DMSO- $d_{6}, 296$ K) $\delta$ ppm: 14.92 (C10); 25.80 (C9); 137.55 (C1); 119.21 (C2); 136.71 (C3); 116.55 (C4); 122.11 (C5); 167.64 (C6); 165.19 (C7); 169.28 (C8).

2.3.5. Synthesis of diiodo-dimethylformamide-(2-hydroxyphenyl-S-ethyldithiocarbazato- $N, O, S)$-tin(Iv) (5). $\mathrm{SnI}_{4}(0.050 \mathrm{~g}$, $0.080 \mathrm{mmol})$ in $3 \mathrm{~mL}$ of absolute ethanol was added to an ethanol $(3 \mathrm{~mL})$ solution of the $\mathrm{L}(0.020 \mathrm{~g}, 0.080 \mathrm{mmol})$ and the mixture refluxed for $1.5 \mathrm{~h}$ on water bath. The resulting solution was kept in a refrigerator for four days. The resulting yellow precipitate was filtered off and dried in a desiccator over silica gel. Crystals suitable for X-ray crystallography were obtained from recrystallization of the precipitate from DMF.

Orange plate-like crystals, yield: $0.04 \mathrm{~g}, 37 \%$ (based on metal salt). Mp: $160{ }^{\circ} \mathrm{C}$. Anal. calc. for $\mathrm{C}_{13} \mathrm{H}_{17} \mathrm{I}_{2} \mathrm{~N}_{3} \mathrm{O}_{2} \mathrm{~S}_{2} \mathrm{Sn}(683.94 \mathrm{~g}$ $\mathrm{mol}^{-1}$ ): C, 22.83; H, 2.51; N, 6.14; S, 9.38. Found: C, 23.35; H, 2.49; N, 6.17; S, 9.17\%. IR (KBr), $\mathrm{cm}^{-1}: \nu(\mathrm{C}=\mathrm{N}) 1647 \mathrm{~s}, \nu(\mathrm{C}-\mathrm{O})$ $1284 \mathrm{~m}, \nu(\mathrm{N}-\mathrm{N}) 10230 \mathrm{w}$. Mass spectrometry, $\mathrm{m} / \mathrm{z}(\%): 683(<1)$ $\{\mathrm{M}\} .{ }^{1} \mathrm{H}-\mathrm{NMR}\left(300 \mathrm{MHz}, \mathrm{DMSO}-d_{6}\right) \delta \mathrm{ppm}: 1.346(\mathrm{t}, 3 \mathrm{H}, J=$ $7.32 \mathrm{~Hz}, \mathrm{C}_{10 \mathrm{H}_{3}}$ ), 3.220 (q, $2 \mathrm{H}, J=7.32 \mathrm{~Hz}, \mathrm{C} \mathrm{H}_{2}$ ), 6.739 (dd, $1 \mathrm{H}$, $J=8.51$ and 1.01, H2), 6.932 (ddd, $1 \mathrm{H}, J=8.02,7.08$ and 1.11, $\mathrm{H} 4), 7.476(\mathrm{~m}, 1 \mathrm{H}, J=7.04$ and 1.82, H3), 7.671 (dd, 1H, $J=7.96$ and $1.77 \mathrm{~Hz}, \mathrm{H} 5), 9.314$ (s, 1H, H7).

2.3.6. Synthesis of dichlorido-dimethylsulfoxide-(2hydroxyphenyl-S-ethyldithiocarbazato- $N, O, S$ )-tin(Iv) (6). A solution of $\mathrm{SnCl}_{2}(0.394 \mathrm{~g}, 2.078 \mathrm{mmol})$ in methanol and DMSO $(3: 1 \mathrm{v} / \mathrm{v})$ was added to the $\mathrm{L}(0.500 \mathrm{~g}, 2.083 \mathrm{mmol})$ in the same solvent $(6 \mathrm{~mL})$. The resulting yellow solution was refluxed for $2 \mathrm{~h}$ on a water bath. Yellow crystals were obtained from slow evaporation of the solvent in a refrigerator over 10 days.

Light-yellow tablet crystals, yield: $0.91 \mathrm{~g}, 87 \%$ (based on metal salt). Mp: $195{ }^{\circ} \mathrm{C}$. Anal. calc. for $\mathrm{C}_{12} \mathrm{H}_{16} \mathrm{Sn} \mathrm{N}_{2} \mathrm{O}_{2} \mathrm{~S}_{3} \mathrm{Cl}_{2}$ (506.6 $\mathrm{g} \mathrm{mol}^{-1}$ ): C, 28.48; H, 3.19; N, 5.54; S, 19.01. Found: C, 28.88; H, 3.16; N, 5.98; S, 19.51\%. IR (KBr), $\mathrm{cm}^{-1}: \nu(\mathrm{C}=\mathrm{N})$ $1600 \mathrm{~s}, \nu(\mathrm{C}-\mathrm{O}) 15340 \mathrm{~m}, \nu(\mathrm{N}-\mathrm{N}) 1030 \mathrm{w}$. Mass spectrometry, $\mathrm{m} / \mathrm{z}$ (\%): $506.8(<1) .{ }^{1} \mathrm{H}-\mathrm{NMR}\left(300 \mathrm{MHz}, \mathrm{DMSO}-d_{6}\right) \delta \mathrm{ppm}: 1.372(\mathrm{t}$, $\left.3 \mathrm{H}, J=7.28 \mathrm{~Hz}, \mathrm{CH}_{3}\right), 2.554\left(\mathrm{~S}, 6 \mathrm{H}, \mathrm{CH}_{3}\right), 3.234(\mathrm{q}, 2 \mathrm{H}, J=$ $7.08 \mathrm{~Hz}, \mathrm{CH}_{2}$ ), 6.982 (m, 1H, H-4), 7.007 (d, 1H, J=1.08, H-2), 7.551 (td, 1H, H-3), 7.677 (dd, 1H, $J=1.87$ and $7.71 \mathrm{~Hz}, \mathrm{H}-5)$, 9.117 (S, 1H, H-7). ${ }^{13} \mathrm{C}-\mathrm{NMR}$ (75.6 MHz, DMSO-d, $296 \mathrm{~K}$ ) $\delta$ ppm: 14.99 (C10); 25.63 (C9); 40.90 (C11, C12); 136.98 (C1); 119.55 (C2); 136.58 (C3); 116.96 (C4); 122.31 (C5); 164.64 (C6); 164.85 (C7); 169.26 (C8).

\subsection{X-ray crystallography}

Suitable crystals of L and 1-6 were mounted on polymer loops and placed in a cold nitrogen stream on a Bruker Smart APEX CCD diffractometer. Full spheres of data were collected under control of the $\mathrm{APE} \times 3$ program suite. ${ }^{26}$ The raw data were converted to $F^{2}$ values with SAINT $^{26}$ and empirical absorption corrections as well as merging of equivalent reflections were performed with SADABS. ${ }^{26}$ The structures were solved by direct methods (SHELXT ${ }^{27}$ ) and refined by full-matrix, least-squares procedures (SHELXL ${ }^{28}$ ). Hydrogen atoms attached to carbon were placed in idealized positions while those attached to oxygen were placed in locations derived from difference maps and their coordinates adjusted to give $\mathrm{O}-\mathrm{H}=0.87 \AA$. All were included as riding contributions with isotropic displacement parameters tied to those of the attached atoms.

\subsection{Biology studies}

2.5.1. Cytotoxicity activity. In order to achieve a better view of potential anticancer properties of the compounds prepared in this work, their cytotoxic activity against the human tumor cell lines Hela and MCF-7 and the normal cell line Cho were determined by MTT assays. For this purpose, $25 \mathrm{~cm}^{2}$ tissue culture flasks were used to grow the cells in an incubator at $37{ }^{\circ} \mathrm{C}$ in a humidified atmosphere consisting of $5 \% \mathrm{CO}_{2}$ and 95\% air. A culture medium of RPMI 1640, 10\% (v/v) fetal bovine

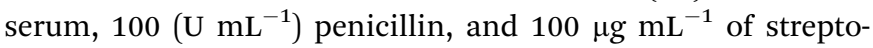
mycin was used to maintain the cells. $100 \mu \mathrm{L}$ volumes of cell solutions were seeded into 96-well plates containing diverse concentrations of $\mathrm{L}$ and its complexes and the mixtures incubated for $48 \mathrm{~h}$. After 48 h, $20 \mu \mathrm{L}$ of MTT [3-(4,5-dimethylthiazol2-yl)-2,5-diphenyl tetrazolium bromide], (final MTT concentration $5 \mathrm{mg} \mathrm{mL} \mathrm{m}^{-1}$ in phosphate buffered saline) solution was added and the samples incubated for $4 \mathrm{~h}$. Finally, $100 \mu \mathrm{L}$ of DMSO is added to each well to dissolve the purple formazan formed. The absorbance $(A)$ of all samples at $570 \mathrm{~nm}$ wavelength was measured by an ELISA plate reader (TECAN infinite M200, Switzerland) at 570/630 $\mathrm{nm}$. All experiments were performed in quadruplicate and evaluated at six concentrations dilution the highest being $200 \mu \mathrm{M}$. The $\mathrm{IC}_{50}$ value was defined as the concentration at which $50 \%$ of the cells could survive. The mean values and standard deviation for treated groups at different times were calculated. In addition, statistical significance of differences between untreated and treated groups at different times was determined by using GraphPad Prism 7.0 software (GraphPad Software, Inc.).

2.5.2. HSA-binding studies. To study the binding of the compounds with HSA, a solution of HSA $(15 \mu \mathrm{M})$ with phosphate buffer solution ( $\mathrm{pH}$ 7.40) was prepared. The exact 
concentration of HSA was determined spectrophotometrically using the molar extinction coefficient of $35700 \mathrm{M}^{-1} \mathrm{~cm}^{-1}$. Samples were prepared by dissolving each compound in DMSO with gradual increase in concentration $(0,1,2$ and $13 \mu \mathrm{M})$ at room temperature. Appropriate concentrations of drug-protein solutions were prepared by mixing protein solutions with different concentrations of drug solutions. The final concentration of DMSO after addition of the drug solution to the protein solution was $1 \%$ of the total volume. For fluorescence determination, spectra $\left(\lambda_{\mathrm{ex}}=280 \mathrm{~nm}\right)$ in the wavelength range of 285-500 $\mathrm{nm}$ were recorded at $298 \mathrm{~K}$ and the slit width was 5/5. Absorption titration experiments with the same concentrations for protein and compounds were also done.

\subsection{X-ray powder diffraction studies}

To prepare the nano-particles, $10 \mathrm{~mL}$ of a $0.01 \mathrm{M}$ solution of the metal salt was positioned in an ultrasonic probe with a maximum power output of $200 \mathrm{~W}$. Into this solution, $10 \mathrm{~mL}$ of a $0.01 \mathrm{M}$ solution of the $\mathrm{L}$ was added dropwise. The precipitate obtained was filtered off and dried in air. The X-ray diffraction pattern of the complexes was determined for a $2 \theta$ range of $6.000^{\circ}$ to $79.990^{\circ}$ using the unit cell data from the single crystal determinations. The morphology and size of the nanoparticles were investigated by scanning electron microscopy (SEM).

\section{Results and discussion}

\subsection{IR and NMR studies}

In the infrared spectrum of L (Fig. SI 1a $\uparrow$ ), a broad, medium intensity band in the region $3200-3400 \mathrm{~cm}^{-1}$ is assigned to the $\mathrm{OH}$ stretching vibration. This band disappears after complexation and indicates the coordination takes place through the deprotonated phenolic oxygen atom. ${ }^{29-31}$ Also the medium intensity $\nu(\mathrm{C}-\mathrm{O})$ band at $\sim 1260 \mathrm{~cm}^{-1}$ in the $\mathrm{L}$ undergoes a blue shift in the complexes (Fig. SI $1 \mathrm{~b}-\mathrm{g} \dagger$ ) which provides further evidence of involving the phenolic oxygen atom in coordination. ${ }^{32}$

The bands at 1307 and $3108 \mathrm{~cm}^{-1}$ are assigned to $\nu(\mathrm{C}=\mathrm{S})$ and $\nu(\mathrm{N}-\mathrm{H})$ vibrations respectively. ${ }^{33,34}$ Disappearance of these bands in the spectra of the complexes suggest the coordination of the $\mathrm{S}$ atom to the metal ion. Also, the absence of a $\nu(\mathrm{S}-\mathrm{H})$ band at approximately $2750 \mathrm{~cm}^{-1}$ emphasizes the existence of the thione tautomeric form in the solid state ${ }^{35} \mathrm{~A}$ strong $\nu(\mathrm{C}=\mathrm{N})$ band is observed at $1613 \mathrm{~cm}^{-1}$ in the $\mathrm{L}$ spectrum which shows a red shift in the metal complexes and confirms coordination of the azomethine nitrogen atom to the metal ion. ${ }^{10,34}$ Finally, $\nu_{\text {sy }}\left(\right.$ cis- $\left.-\mathrm{MoO}_{2}\right), \quad \nu_{\text {asy }}\left(\text { cis- }-\mathrm{MoO}_{2}\right)^{36}$ and $\nu(\mathrm{V}=\mathrm{O})^{37,38}$ frequencies appear at 842,929 and $990 \mathrm{~cm}^{-1}$ respectively. ${ }^{39}$

In the ${ }^{1} \mathrm{HNMR}$ spectra of compounds (Fig. SI $2 \mathrm{a}-\mathrm{e} \dagger$ ), the aromatic protons are observed as multiplet signals in the range 6.5-7.9 $\mathrm{ppm}^{.0}{ }^{40}$ The triplet and quartet signals which are, respectively, observed in the ranges 1.2-1.4 and 3.2-4.2 ppm correspond to the ethyl protons. ${ }^{41}$ In the spectrum of the ligand $(\mathrm{L})$, however, the sharp signal at $10.26 \mathrm{ppm}$ is assigned to the phenolic proton as it disappears upon $\mathrm{D}_{2} \mathrm{O}$ addition (Fig. SI $\left.2 f^{\dagger}\right) .{ }^{42}$ The absence of this signal in the spectra of the complexes confirms that coordination occurs through the phenolic oxygen ${ }^{43}$ Also the singlet signal assigned to the imine hydrogen in the L spectrum $(8.54 \mathrm{ppm})$ shifts down field after complexation $^{44,45}$ while satellites appear around this signal in compounds 4-6 which correspond to coupling of this hydrogen with ${ }^{117} \mathrm{Sn}$ and ${ }^{119} \mathrm{Sn}$ isotopes, ${ }^{46}$ all of which indicate coordination of this nitrogen atom.

In the ${ }^{13} \mathrm{C}-\mathrm{NMR}$ spectra of the compounds (Fig. SI $3 \mathrm{a}-\mathrm{e} \dagger$ ), signals of the aromatic carbons are in the range 116-164 pm. The signals of the thioamide and azomethine carbons in the $\mathrm{L}$ spectrum are observed at 196 and $145 \mathrm{ppm}$ respectively and are shifted upfield after complexation. ${ }^{47}$ This indicates that the thioamide and azomethine carbons are close to complexation sites (see Experimental section for more details about other carbons). ${ }^{48}$

\subsection{Thermogravimetric analysis}

TGA and DTG curves of complexes 1-6 (Fig. SI 4a-f $\dagger$ ) were carried out over a temperature range from room temperature up to $950{ }^{\circ} \mathrm{C}$. The thermal studies using TGA methods show a multistep decomposition pattern in the thermograms of the metal complexes under investigation.

The data from thermogravimetric analysis show that decomposition of compound $\mathbf{1}$ occurs in four steps. The degradation starts over the temperature range $28-145^{\circ} \mathrm{C}$ with a mass loss of $7.90 \%$ (calc. $8.04 \%$ ), consistent with removal of the coordinated methanol molecule. Next, weight losses of $26.79 \%$ (calc. $26.40 \%$ ) and $28.83 \%$ (calc. $29.40 \%$ ) are associated with removal of the coordinated $\mathrm{L}^{\prime}$ which occurs in two consecutive steps over the temperature range $224-719{ }^{\circ} \mathrm{C}$. The remaining residue $(35.22 \%$ of the initial mass) is formulated as $\mathrm{MoO}_{3}$ (calc. 36.14\%). ${ }^{12,49}$

The vanadium complex (2) also, in the first stage of its thermal decomposition, involves loss of the coordinated methanol molecule (8.63\% mass loss; calc. $8.69 \%)$ over the temperature range of $21-113{ }^{\circ} \mathrm{C}$. In the second step, the methoxide ligand is removed by further heating to $217{ }^{\circ} \mathrm{C}(8.30 \%$ mass loss; calc. $8.42 \%$ ). Then, the $\mathrm{L}^{\prime}$ ligand is removed in three steps with a total mass loss of $60.39 \%$ (calc. $60.35 \%$ ) over the temperature range $178-743{ }^{\circ} \mathrm{C}$ and $\mathrm{VO}_{2}$ remains as the final product with a mass of $26.60 \%$ (calc. $22.51 \%$ ). ${ }^{49}$

Complex 3 decomposes in three steps. No weight loss is seen up to $150{ }^{\circ} \mathrm{C}$. The coordinated $\mathrm{L}^{\prime}$ in two consecutive steps are eliminated over the temperature range $153-570{ }^{\circ} \mathrm{C}$ with a mass loss of $22.76 \%$ (calc. $23.02 \%$ ) for release of $S$-ethyl groups and a mass loss of $32.96 \%$ (calc. $33.61 \%$ ) for release of another part of the $\mathrm{L}^{\prime}$ ligand. The residue at the temperature of $570{ }^{\circ} \mathrm{C}$ is a mixture of metal oxides comprising $25.59 \%$ of the initial mass which at $822{ }^{\circ} \mathrm{C}$ converts to $\mathrm{Mn}_{2} \mathrm{O}_{3}$ with a mass of $19.21 \%$ (calc. $21.40 \%)^{50-52}$

TGA and DTG curves of $\mathbf{4}, \mathbf{5}$ and $\mathbf{6}$ shows two thermal decomposition stages and for all the three complexes, $\mathrm{SnO}_{2}$ remains as the final product. ${ }^{46}$

In $\mathbf{4}$, the first step consists of the loss of iodine groups and coordinated dimethyl formamide molecule with a mass of $42.88 \%$ (calc. $47.80 \%$ ) at temperature range of $100-370{ }^{\circ} \mathrm{C}$. The 


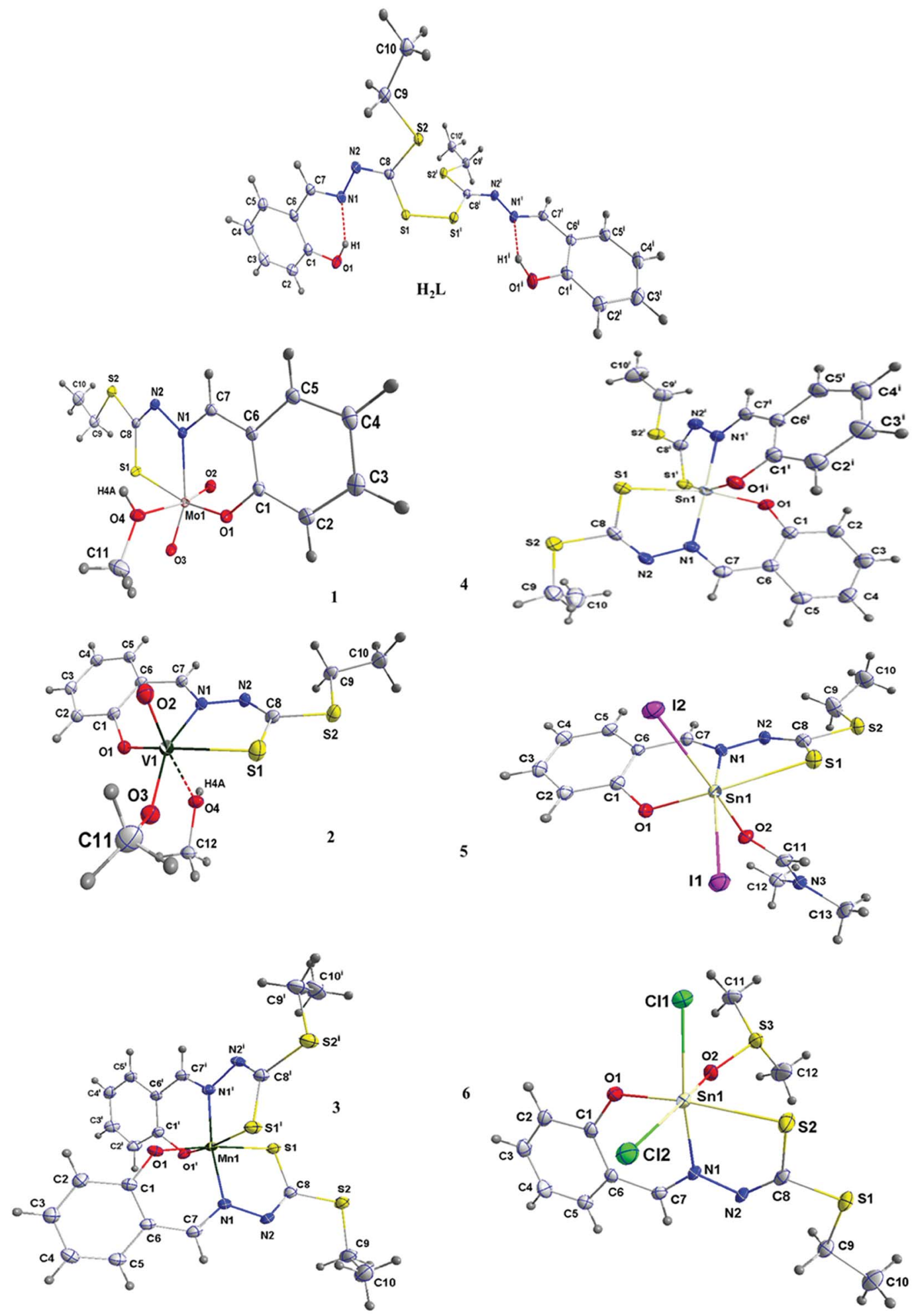

Fig. 1 Views of L ligand and complexes showing the atomic numbering and 50\% probability displacement ellipsoids.

second step indicates the decomposition of the organic part $\left(\mathrm{L}^{\prime}\right)$ up to $590{ }^{\circ} \mathrm{C}$ with mass loss of $30.52 \%$ (calc. $32.50 \%$ ) and formation of $\mathrm{SnO}_{2}$.

Likewise, in 5, the first step involves the removal of dimethyl sulfoxide molecule, chlorine atoms and $\mathrm{CS}_{2}$-ethyl group with a mass of $46.19 \%$ (calc. $50.25 \%$ ) at temperature range of $21-$
$357{ }^{\circ} \mathrm{C}$. By increasing of temperature up to $725{ }^{\circ} \mathrm{C}$, the residual organic part decomposes with a loss of $26.36 \%$ (calc. $26.13 \%$ ) of the complex mass, and the $\mathrm{SnO}_{2}$ with mass of $26.40 \%$ (calc. $29.79 \%$ ) remains as the final product.

Finally, compound 6 is stable up to $195^{\circ} \mathrm{C}$. The $\mathrm{L}^{\prime}$ removes during two steps at temperature range of $195-580{ }^{\circ} \mathrm{C}$ and the 


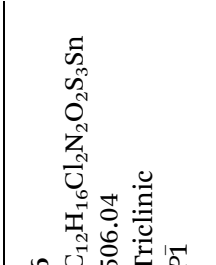

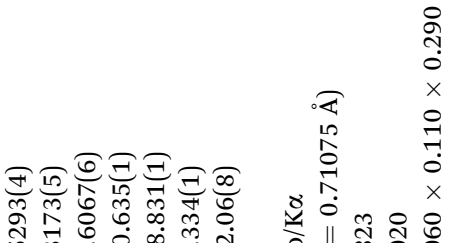

ஷั่

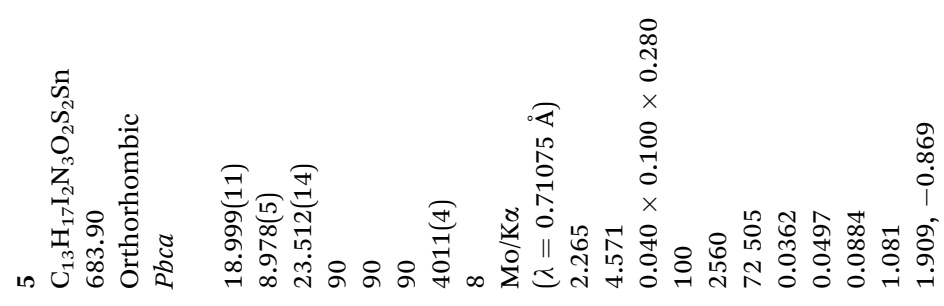
तै $\vec{m}$ :

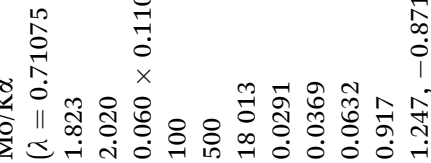

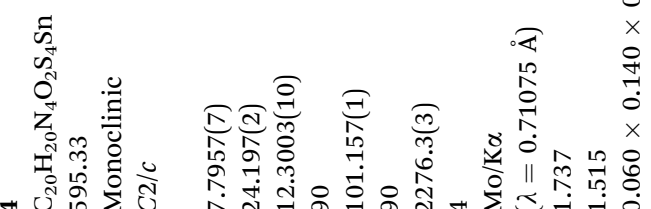

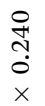

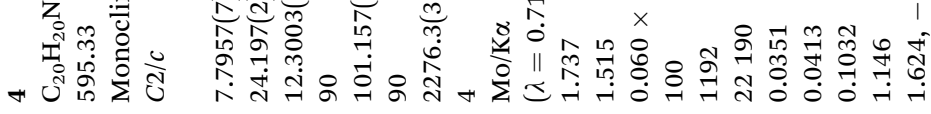

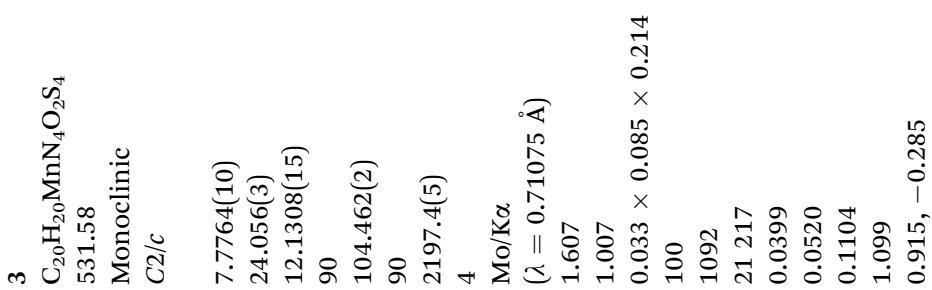

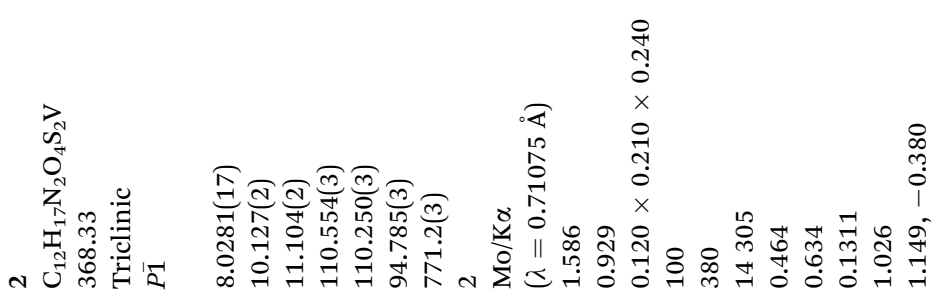

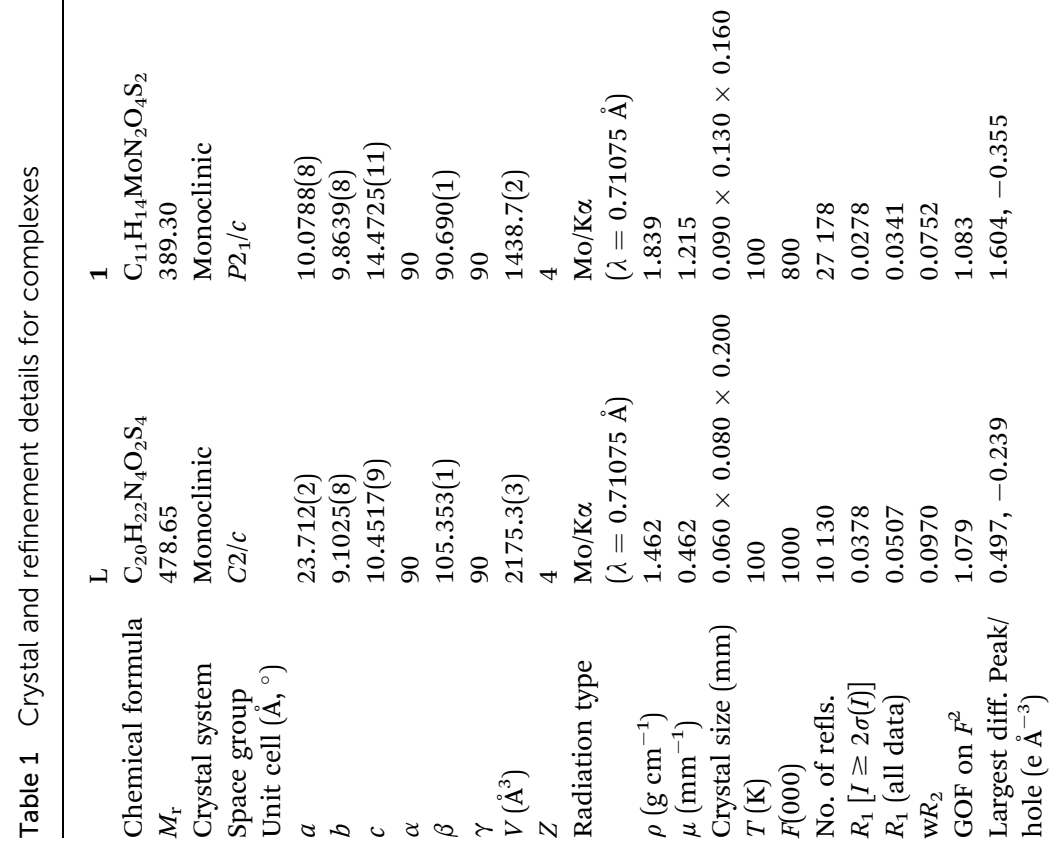


$\mathrm{SnO}_{2}$ with mass loss of $22.7 \%$ (calc. $25.31 \%$ ) remains as the final product.

\subsection{X-ray crystal structures}

Molecular structures were determined by single crystal X-ray diffraction for the L and all six complexes and ORTEP drawings are shown in Fig. 1. Crystal data and refinement results for the compounds are listed in Table 1.

The sample of the L ligand material used for the X-ray structure was found to be a dimer with an S-S bond. Formation of the S-S bond is a consequence of S-H oxidation which is a phenomenon which frequently happen in the amino acid cysteine (Scheme 1). ${ }^{45}$

The $\mathrm{S}-\mathrm{S}$ bond length in hydrogen disulfide is $2.06 \AA$, however, formation of this bond with a length of $2.045 \AA$ in the $\mathrm{L}$ is close to the length of the bond in other compounds. ${ }^{53}$ The torsion angle $\mathrm{S} 1^{\prime}-\mathrm{S} 1-\mathrm{C} 8-\mathrm{S} 2(-8.86(8) \AA)$ shows that the molecule is not planar and is twisted. In fact, the two equal fragments are perpendicular to each other in the molecule. The intramolecular $\mathrm{O} 1-\mathrm{H} 1 \cdots \mathrm{N} 1$ hydrogen bonding creates a $\mathrm{S}_{1}{ }^{1}(6)$ graph set. Also, another intramolecular interaction between the $\mathrm{S} 1$ and $\mathrm{O} 1$ atoms leads to formation of a nine-membered ring (S1/C8/N2/N1/C7/C6/C1/O1/H1) with $\mathrm{S}_{1}{ }^{1}$ (9) graph set (Fig. 2).

Adjacent molecules connect to each other by $\mathrm{C} 10-\mathrm{H} 10 \mathrm{~A} \cdots$ $\mathrm{O}^{i}{ }^{2}(2.644 \AA$ ) (symm. code $i: 1-x, 1-y,-z$ ) and $\mathrm{C} 7-\mathrm{H} 7 \cdots \mathrm{O} 1$ $(2.692 \AA)$ hydrogen bonds along the $c$ axis. Additionally, the C5H5 ${ }^{\cdots} \mathrm{C}_{\mathrm{g}}{ }^{i i}\left(\mathrm{C}_{\mathrm{g}}\right.$ : $\left.\mathrm{C} 1-\mathrm{C} 6\right)(3.715 \AA)$ (symm. code $\left.i i: 1-x, 1-y, 1-z\right)$ interaction plays a decisive role in the development of these chains. These chains expand through $\mathrm{C} 2-\mathrm{H} 2 \cdots \mathrm{C}_{\mathrm{g}}{ }^{i i i}\left(\mathrm{C}_{\mathrm{g}}: \mathrm{C} 1-\mathrm{C} 6\right)$ $(2.865 \AA$ ) (symm. code iii: $1-x, 1-y, 1-z)$ interaction in the bc plane and complete second and third dimensions (Fig. SI 5a and $\mathrm{b} \dagger)$.

In the complexation the $\mathrm{S}-\mathrm{S}$ bond of the $\mathrm{L}$ is broken and two $\mathrm{L}^{\prime}$ is formed (Scheme 1). The $\mathrm{L}^{\prime}$ ligand acts as a tridentate chelate and connects to the metal ion through the deprotonated phenolic oxygen, the azomethine nitrogen and the thioamide sulfur atom in 1-6. All the complexes are six coordinated and exhibit a distorted octahedral configuration. The asymmetric units of 1, 3, 4 and 5 are composed of one complete molecule and for $\mathbf{2}$ and $\mathbf{6}$ only half of the molecule lies in the asymmetric unit. Selected bond lengths and angles are listed in Table 2.

In all these complexes, the coordination of the $\mathrm{L}^{\prime}$ to the central metal forms one five- and one six-membered chelate ring. These two rings are not coplanar and therefore it can be concluded that the $\mathrm{L}^{\prime 2-}$ is coordinated to the central metal with steric strain. Moreover, the greater electronegativity of oxygen atom over sulfur atom causes shortening of the oxygen-metal bond which leads to an out-of-plane orientation of the oxygen atom within the six-membered ring. Among these complexes, compound 5 has the longest M-S bond (2.4910(16) $⿱$ ) which causes the greatest amount of oxygen atom deviation $(0.278 \AA)$ from the M, N1, C7, C6, C1, O1 mean plane and compound 2 has the shortest $\mathrm{M}-\mathrm{O}$ bond $(1.869(17) \AA)$. In 1 , the $\mathrm{O} 1$ atom bears such a strain that it is $0.16 \AA$ off the mean plane of the sixmembered ring (Mo1, N1, C7, C6, C1, O1). The Mo1-O1 and Mo1-S1 bond lengths are 1.9284(14) and 2.4568(5) A respectively. However, the Mo1-O2 (1.702(2) Å) and Mo1-O3 (1.703(1) A) bonds are approximately the same length, which confirms the equal distribution of electron density of oxido atoms around the central metal. Oxido atoms, $\mathrm{O} 2$ and $\mathrm{O} 3$, are oriented cis to each other with an angle of 105.46(7) . All lengths and angles around the central atom are almost equal to those of the similar compounds reported elsewhere. ${ }^{54-56}$ The $\mathrm{L}^{\prime}$ and $\mathrm{O} 3$ atom occupy the equatorial positions while methanol solvent and the $\mathrm{O} 2$ atom are in axial positions. The $\mathrm{O} 2$ and $\mathrm{O} 4$ atoms are trans relative to each other with angle of $169.59(7)^{\circ}$. In this compound, the adjacent molecules form a dimer with an $\mathrm{R}_{2}{ }^{2}(10)$ graph set through pairwise hydrogen bond of $\mathrm{O} 4-\mathrm{H} 4 \mathrm{~A} \cdots$ $\mathrm{N} 2{ }^{i}(1.913(2) \AA)$ (symm. code $\left.i: 1-x, 1-y, 1-z\right)$. These dimers connect to each other through the hydrogen bond $\mathrm{C} 9^{\mathrm{i} i}-\mathrm{H} 9 \mathrm{~A}^{i i} \ldots$ O2 (2.543 $\AA$ ) (symm. code $i i: x, 1.5-y, 1 / 2+z)$ and form a onedimensional chain in the direction of the $(-567)$ plane. Likewise, through $\mathrm{C} 9-\mathrm{H} 9 \mathrm{~A} \cdots \mathrm{O} 2^{i i i}$ and $\mathrm{C} 4-\mathrm{H} 4 \mathrm{~A} \cdots \mathrm{S} 1^{i v}(2.961 \AA)$ (symm. code iii and $i v: 1-x, 1 / 2+y, 1 / 2-z$ and $x,-1+y, z$ ) hydrogen bonds the second dimension forms along the $b$ axis. The planes thus created connect to each other through $\mathrm{C} 2-\mathrm{H} 2 \cdots$
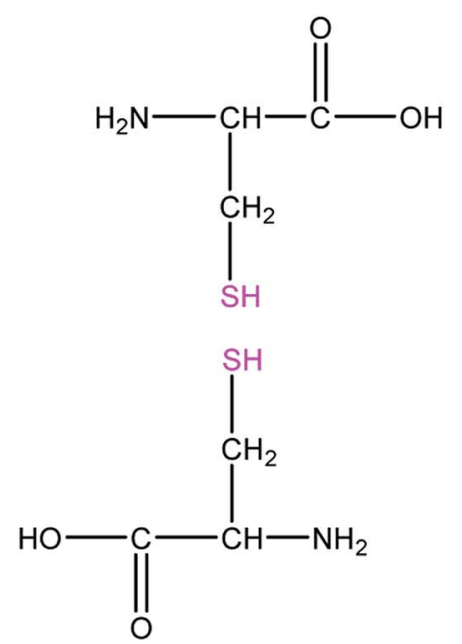

Scheme 1 Formation of the S-S bond in cysteine.
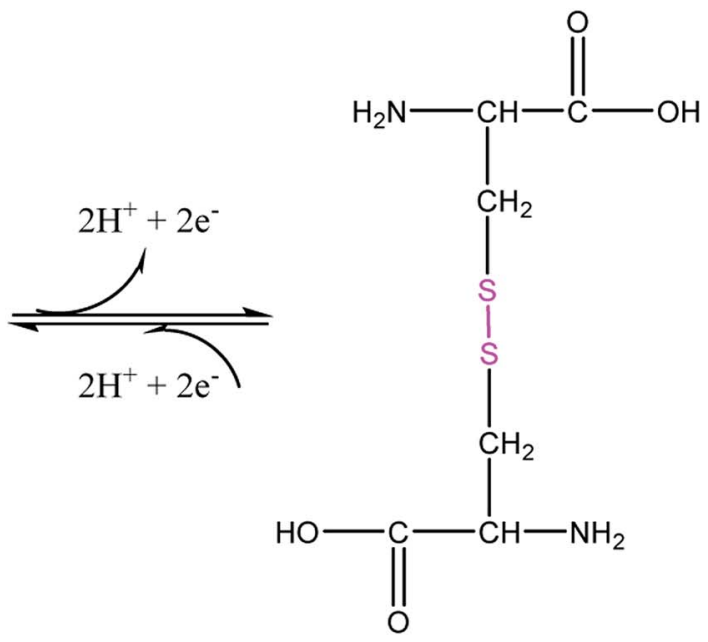


列

Fig. 2 Display of the intramolecular hydrogen bonds.

$\mathrm{O}^{v}$ (2.606 $\AA$ ) (symm. code $v: x, 1.5-y, 1 / 2+z$ ) hydrogen bonds along the $c$ direction to generate the three dimensional structure (Fig. SI $5 \mathrm{c}-\mathrm{f}_{\dagger} \dagger$ ).

In complex 2, also due to steric strain the vanadium center moves from the mean coordination plane toward the axial position by about $0.303(3) \AA$. The axial positions are occupied by the methanol and $\mathrm{O} 2$ atom and the $\mathrm{L}^{\prime}$ ligand and methoxy groups fill the equatorial positions. The angle between the $\mathrm{O} 2$ and $\mathrm{O} 4$ atoms $\left(172.98(8)^{\circ}\right)$ is higher than compound $\mathbf{1}$. In this crystalline structure, just like $\mathbf{1}$, adjacent molecules form dimers and create ten member graph set $\mathrm{R}_{2}{ }^{2}(10)$ through pairwise hydrogen bonds O4-H4A $\cdots \mathrm{N} 2^{i}(1.963 \AA$ ) (symm. code $i$ : $1-x, 1-y, 1-z)$. The preformed dimers form onedimensional chains in the direction of the $c$ axis through the hydrogen bonds C9-H9A $\cdots \mathrm{C}_{g}, \mathrm{C} 12-\mathrm{H} 12 \mathrm{C} \cdots \mathrm{O} 2^{i i}(2.681 \AA)$ and $\mathrm{C} 5^{i}-\mathrm{H} 5^{i} \cdots \mathrm{O} 2^{i i i}(2.665 \AA$ ) (symm. code $i i: 2-x, 1-y, 1-z, i i i:-1$ $+x, y, z$ ). Moreover, the $\mathrm{C} 2-\mathrm{H} 2 \cdots \mathrm{O} 1^{i v}$ (symm. code $i v: 1-x, 1-$ $y,-z$ ) hydrogen bond is responsible for the formation of the second dimension along the $a c$ plane and the last dimension is formed through $\mathrm{C} 4-\mathrm{H} 4 \cdots \mathrm{S}^{v}$ and $\mathrm{C} 5-\mathrm{H} 5 \cdots \mathrm{C} 11^{\nu i}$ (symm. code $v$ : $x,-1+y,-1+z, v i: x,-1+y, z)$ interactions along the $b$ axis (Fig. SI $5 \mathrm{~g}-\mathrm{j} \dagger$ ).

Table 2 Selected bond lengths $(\AA \AA)$ and angles $\left(^{\circ}\right)$

\begin{tabular}{|c|c|c|c|c|c|c|c|}
\hline & $\mathrm{L}$ & 1 & 2 & 3 & 4 & 5 & 6 \\
\hline C7-N1 & $1.2864(18)$ & $1.300(2)$ & $1.301(3)$ & $1.298(3)$ & $1.290(3)$ & $1.301(6)$ & $1.286(3)$ \\
\hline C8-N2 & $1.2859(17)$ & $1.300(3)$ & $1.311(3)$ & $1.296(3)$ & $1.302(4)$ & $1.301(6)$ & $1.289(3)$ \\
\hline S1-C8 & $1.7917(13)$ & $1.729(2)$ & $1.719(2)$ & $1.735(2)$ & $1.741(3)$ & $1.753(5)$ & $1.739(3)$ \\
\hline S2-C8 & $1.7413(13)$ & $1.742(2)$ & $1.746(2)$ & $1.747(2)$ & $1.754(3)$ & $1.754(5)$ & $1.760(3)$ \\
\hline C1-C6 & $1.4106(19)$ & $1.408(3)$ & $1.416(3)$ & $1.420(3)$ & $1.418(4)$ & $1.423(6)$ & $1.426(4)$ \\
\hline C1-O1 & $1.3516(17)$ & $1.349(2)$ & $1.340(3)$ & $1.330(2)$ & $1.339(3)$ & $1.343(5)$ & $1.338(3)$ \\
\hline N1-N2 & $1.4050(16)$ & $1.397(2)$ & $1.414(3)$ & $1.410(2)$ & $1.395(3)$ & $1.401(5)$ & $1.406(3)$ \\
\hline S2-C9 & $1.8201(14)$ & $1.807(2)$ & $1.818(3)$ & $1.822(2)$ & $1.821(3)$ & $1.820(5)$ & $1.818(3)$ \\
\hline M1-N1 & - & $2.2821(16)$ & $2.152(2)$ & $1.9836(16)$ & $2.173(2)$ & $2.203(4)$ & $2.183(2)$ \\
\hline M1-S1 & - & $2.4568(5)$ & $2.4183(9)$ & $2.3196(6)$ & $2.4827(7)$ & $2.4910(16)$ & $2.4624(7)$ \\
\hline M1-O1 & - & $1.9284(14)$ & $1.8699(17)$ & $1.9036(15)$ & $2.045(2)$ & $2.040(3)$ & $2.0109(18)$ \\
\hline M1-O2 & - & $1.7017(16)$ & $1.5904(18)$ & - & - & $2.220(3)$ & $2.1662(17)$ \\
\hline S1-C8-S2 & $103.83(4)$ & $119.81(12)$ & 126.61(19) & $113.70(12)$ & $111.35(15)$ & $111.6(2)$ & $111.13(15)$ \\
\hline $\mathrm{N} 1-\mathrm{N} 2-\mathrm{C} 8$ & $111.96(11)$ & $115.03(16)$ & $112.12(19)$ & $111.69(16)$ & $114.2(2)$ & $114.5(4)$ & $115.6(2)$ \\
\hline $\mathrm{O} 1-\mathrm{C} 1-\mathrm{C} 6$ & $122.28(12)$ & $121.64(18)$ & $120.5(2)$ & $122.81(18)$ & $124.1(2)$ & $123.5(4)$ & $124.7(2)$ \\
\hline $\mathrm{C} 7-\mathrm{N} 1-\mathrm{N} 2$ & $113.72(11)$ & $113.30(16)$ & $113.57(19)$ & $115.13(16)$ & $116.3(2)$ & $114.8(4)$ & $115.8(2)$ \\
\hline C8-S2-C9 & $99.47(6)$ & $104.36(10)$ & $104.66(12)$ & $103.08(10)$ & $103.69(14)$ & $102.8(2)$ & $102.32(13)$ \\
\hline $\mathrm{N} 2-\mathrm{C} 8-\mathrm{S} 2$ & $121.76(10)$ & $113.75(14)$ & $120.26(18)$ & $120.37(15)$ & $119.4(2)$ & $118.7(3)$ & $120.0(2)$ \\
\hline $\mathrm{O} 2-\mathrm{M} 1-\mathrm{O} 1$ & - & $100.02(7)$ & $99.83(8)$ & - & - & $82.32(13)$ & $81.51(7)$ \\
\hline O2-M1-N1 & - & $93.99(6)$ & $94.44(8)$ & - & - & $79.97(13)$ & $83.41(7)$ \\
\hline O1-M1-N1 & - & $82.42(6)$ & $84.55(8)$ & $91.67(6)$ & $86.46(8)$ & $84.26(13)$ & $87.84(7)$ \\
\hline N1-M1-S1 & - & $76.14(4)$ & $77.54(6)$ & $82.07(5)$ & $79.25(6)$ & $79.24(10)$ & $80.32(6)$ \\
\hline O1-M1-S1 & - & $154.98(5)$ & $156.89(6)$ & $91.46(5)$ & $165.58(6)$ & $161.79(10)$ & $165.95(5)$ \\
\hline $\mathrm{O} 2-\mathrm{M} 1-\mathrm{S} 1$ & - & $94.24(6)$ & $96.04(7)$ & - & - & $87.24(10)$ & $89.59(5)$ \\
\hline $\mathrm{O} 2-\mathrm{M} 1-\mathrm{O} 3$ & - & $105.46(7)$ & $102.95(9)$ & - & - & - & - \\
\hline C8-S1-M1 & - & $100.08(7)$ & $98.73(8)$ & $94.10(7)$ & $92.60(9)$ & 93.97(15) & $102.32(13)$ \\
\hline
\end{tabular}


Table $3 \quad I C_{50}$ values (mean $\pm \mathrm{SD}^{a}(\mu \mathrm{M})$ ) of compounds against three of cell lines

\begin{tabular}{lccl}
\hline & \multicolumn{3}{l}{$\mathrm{IC}_{50} \pm \mathrm{SD}(\mu \mathrm{M})^{a}$} \\
\cline { 2 - 4 } Cell lines & Hela & MCF-7 & CHO \\
\hline $\mathrm{L}$ & $0.1766 \pm 0.022$ & $0.4762 \pm 0.0261$ & $0.4698 \pm 0.0236$ \\
$\mathbf{1}$ & $0.846 \pm 0.023$ & $1.067 \pm 0.0223$ & $0.6628 \pm 0.224$ \\
$\mathbf{2}$ & $0.0506 \pm 0.0226$ & $0.6692 \pm 0.0243$ & $0.9544 \pm 0.0186$ \\
$\mathbf{3}$ & $0.3415 \pm 0.0232$ & $0.7031 \pm 0.0241$ & $0.8267 \pm 0.025$ \\
$\mathbf{4}$ & $0.6842 \pm 0.012$ & $0.5862 \pm 0.0244$ & $1.456 \pm 0.0246$ \\
$\mathbf{5}$ & $0.6842 \pm 0.02$ & $1.048 \pm 0.0247$ & $0.3179 \pm 0.0254$ \\
$\mathbf{6}$ & $0.05065 \pm 0.0226$ & $0.7018 \pm 0.0247$ & $1.236 \pm 0.0262$ \\
Cisplatin & $0.324 \pm 0.023$ & $0.67430 \pm 0.023$ & $1.347 \pm 0.025$
\end{tabular}

${ }^{a}$ Data are presented as mean \pm SD (standard deviation). All experiments were independently performed at least four times.

In compounds 3 and $\mathbf{4}$, the central metal in its +IV oxidation state surrounded by two tridentate chelate ligands $\left(\mathrm{L}^{\prime}\right)$. In 3 and 4, respectively, the two $\mathrm{L}^{\prime}$ coordinate to the manganese and tin ions through the deprotonated phenol oxygen, the azomethine nitrogen and the thioamide sulfur donor atoms. In the coordination sphere, the two phenolic oxygen atoms are cis to one another as are the thioamide sulfur atoms with the two azomethine nitrogen atoms disposed trans to one another. The $\mathrm{O} 1$ atom deviation from the coordination plane is $0.217 \AA$ and $0.227 \AA$ in 3 and 4 respectively. It seems that steric strain is higher in 4. However, in both compounds the $\mathrm{C} 4-\mathrm{H} 4 \cdots \mathrm{S} 1^{i}$ (2.920 ̊ for 3 and $2.883 \AA$ for 4) (symm. code $i:-1 / 2+x, 1 / 2+y$, $1 / 2+z$ ) interaction leads to formation of one-dimensional chains in the $-a+c$ direction. These chains within the $(-10-1)$ plane form $2 \mathrm{D}$ sheets through chalcogen-chalcogen $\mathrm{S} 2 \cdots \mathrm{S} 2{ }^{i i}(i i:-1+x, 1-y, 1 / 2+z)(3.403 \AA)$ interactions and finally the planes expand by $\mathrm{C} 9-\mathrm{H} 9 \mathrm{~B} \cdots \mathrm{C} 9^{\text {iii }}$ (iii: $\left.-1+x, y,-1+z\right)$ interactions to construct the $3 \mathrm{D}$ supramolecular network (Fig. SI 5k-m†).
In the structure of $\mathbf{5}$, the deprotonated $\mathrm{L}^{\prime}$ and one iodine atom are located in equatorial positions and the other iodine atom and the DMF solvent are placed in the axial position. Iodine atoms are positioned cis relative to each other $\left(97.84(2)^{\circ}\right)$ which angle is $7^{\circ}$ higher than the idealized $90^{\circ}$ for a regular octahedron geometry. Interactions such as C9-H9A $\cdots \mathrm{N} 2^{i}, \mathrm{C} 13-$ $\mathrm{H} 13 \mathrm{C} \cdots \mathrm{I} 1^{i i}(3.047 \AA)$ and $\mathrm{C} 7-\mathrm{H} 7 \cdots \mathrm{C}_{\mathrm{g}}{ }^{i}$ (symm. code $i: 1.5-x,-1$ / $2+y, 1-z$, ii: $x,-1+y, z)$ creates chains along the $b$ axis direction. The hydrogen bonding C13-H13B $\cdots \mathrm{S} 2^{i i i}(2.985 \AA)$, $\mathrm{C} 12-\mathrm{H} 12 \mathrm{~A} \cdots \mathrm{O} 1^{v i}(2.451 \AA)$ and $\mathrm{C} 11-\mathrm{H} 11 \cdots \mathrm{S} 2^{i i i}(2.975 \AA$ ) (symm. code iii: $1-x,-y, 1-z$, vi: $1 / 2+x,-1+y, 1 / 2-z)$ forms the second dimension along the $-a+c$ direction. The last dimension is formed along the $-a-c$ direction through $\mathrm{C}_{12} 2^{v}-\mathrm{H} 12 \mathrm{~A}^{v} \ldots$ $\mathrm{O} 1, \mathrm{C} 11^{v i}-\mathrm{H} 11^{v i} \cdots \mathrm{S} 2^{v i}$ and $\mathrm{C} 13^{v i}-\mathrm{H} 13 \mathrm{~B}^{v i} \cdots \mathrm{S} 2^{v i}$ (symm. code $v: 1$ $-x,-1.5+y, 1 / 2+z, v i: 1 / 2+x, 1 / 2-y, 1-z)$ hydrogen bonds (Fig. SI 5n-p $\dagger$ ).

The crystalline structure of $\mathbf{6}$ is similar to that of $\mathbf{5}$, in which the two chlorine atoms are arranged cis to each other $\left(96.81(3)^{\circ}\right)$ and the angle is $6^{\circ}$ higher than the idealized $90^{\circ}$ for a regular octahedron geometry and $2^{\circ}$ higher than the reported similar structure by Souse et al.,$^{57}$ Therefore, the polyhedron around the $\mathrm{Sn}$ (Iv) atom is best described as a distorted octahedral. The deprotonated $\mathrm{L}^{\prime}$ and one chlorine atom are located at the equatorial positions and the other chlorine atom and the DMSO solvent are in the axial positions.

The three-dimensional structure is formed according to the following interactions. The $\mathrm{C} 11-\mathrm{H} 11 \mathrm{~A} \cdots \mathrm{C} 10^{i}(2.899 \AA)$, C7$\mathrm{H} 7 \cdots \mathrm{Cl} 2^{i i}(2.819 \AA), \mathrm{C} 10-\mathrm{H} 10 \mathrm{C} \cdots \mathrm{Cl} 2^{i i}(3.397 \AA)$ and $\mathrm{H} 12 \mathrm{~B}-$ $\mathrm{C} 12 \cdots \mathrm{Cl} 2(2.868 \AA$ ) interactions (symm. code $i: x, y,-1+z, i i: 2$ $-x, 1-y, 1-z$ ) form chains along the $c$ axis direction. The molecules form the second dimension along the $a$ axis direction via the hydrogen bonds $\mathrm{C} 11-\mathrm{H} 11 \mathrm{~A} \cdots \mathrm{Cl} 2{ }^{i i i}, \mathrm{C} 12-\mathrm{H} 12 \mathrm{C} \cdots \mathrm{Cl} 1^{i i i}$ and $\mathrm{C} 11-\mathrm{H} 11 \mathrm{~B} \cdots \mathrm{C}_{\mathrm{g}}{ }^{i v}$ (symm. code iii: $-1-x, y, z, i v: 1-x, 1-$ $y,-z)$. The $\mathrm{C} 4-\mathrm{H} 4 \mathrm{C} \cdots \mathrm{Cl} 2^{v}$ (symm. code $\left.v: x, 1+y, z\right)$ interaction along the $b$ axis forms the third dimension (Fig. SI $5 \mathrm{q}-\mathrm{s} \dagger$ ).

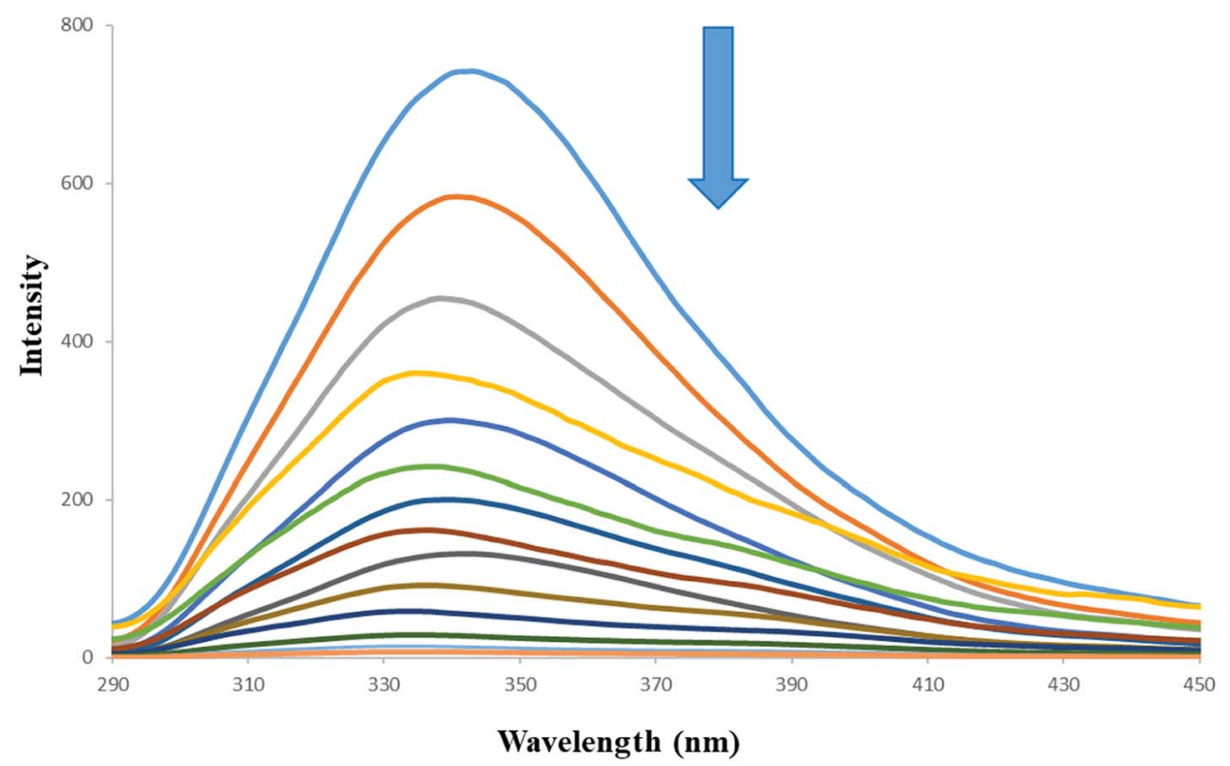

Fig. 3 Fluorescence quenching spectra of HSA in the presence of increasing concentration of $L$. $[H S A]=15 \mu M,[L]=0-14 \mu M, \lambda$ ex $=280 \mathrm{~nm}, T=$ $298 \mathrm{~K}$. 

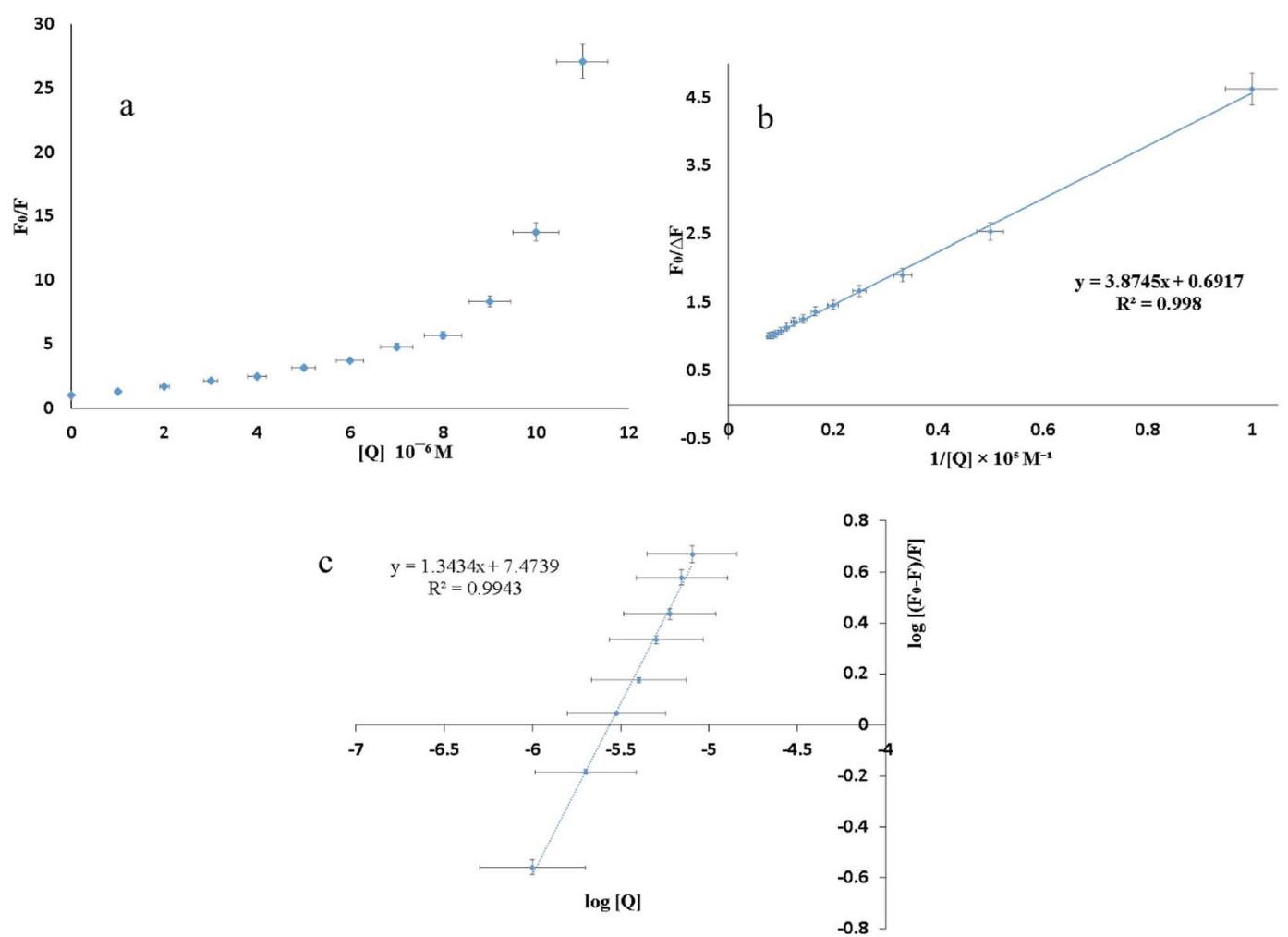

Fig. 4 (a) Stern-Volmer plot for quenching of HSA (15 $\mu$ M) fluorescence by $L$ at different concentrations $\left(\lambda_{\mathrm{ex}}=280 \mathrm{~nm}\right.$, $\left.\lambda_{\mathrm{em}}=343 \mathrm{~nm}\right) ;(\mathrm{b}) \mathrm{plot}$ of $\frac{F_{0}}{F_{0}-F}$ Vs. $1 /\left[\mathrm{L}^{2-}\right]$ for HSA in the presence of increasing concentrations of $L$ at $T=298 \mathrm{~K}\left(\lambda_{\mathrm{ex}}=280 \mathrm{~nm}, \lambda_{\mathrm{em}}=343 \mathrm{~nm}\right)$; (c) double-log plots for the fluorescence quenching of the HSA by L.

All bond lengths in these compounds are similar to those observed in reported compounds. ${ }^{15,58,59}$ The S1-C8 and S2-C8 bond distances are in the range 1.729(2) ̊ to 1.792(13) $\mathrm{A}$ for the new compounds which suggest the $\mathrm{S}-\mathrm{C}$ bond is very close to a single bond. The N1-C8 and N2-C8 bond lengths are between

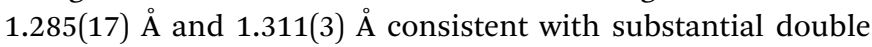
bond character. The observed values for the N1-N2 bond

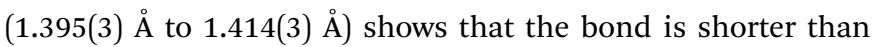
a single $\mathrm{N}-\mathrm{N}$ bond $(1.44 \AA)$. This variation in bond lengths shows that a significant $\pi$-charge delocalization occurs within the SSCNNC fragment.

\subsection{In vitro cytotoxicity study}

To use a substance as a drug, a cytotoxicity test is required. If it does not show cytotoxicity or just reveals a lower level than the determined standards and if other tests are passed it could enter the pharmaceutical marketing. One of the most important methods to measure cytotoxicity is the MTT assay ${ }^{60}$ MTT is a compound that reduces in the presence of mitochondria dehydrogenase enzyme and its yellow color changes to violet.
Color intensity is proportional to the number of live cells. ${ }^{61}$ In this method, the cell is exposed to various concentrations of the target material and then evaluated for cell death indices..$^{62,63}$

The in vitro cytotoxicity evaluation results in three cell lines for the $\mathrm{L}$ and complexes 1-6 are summarized in Table 3 (see graphs in Fig. SI $6 \mathrm{a}-\mathrm{c} \dagger$ ).

Cytotoxicity evaluation results reveal that all complexes exhibit good cytotoxic activity. $\mathrm{L}$ and complexes $\mathbf{2}$ and $\mathbf{6}$ showed $\mathrm{IC}_{50}$ values lower than cisplatin against Hela cell and likewise complexe $\mathbf{4}$ and L against MCF-7 cell which indicating a greater cytotoxicity and anticancer activity of these compounds. So, complex 2 and L show better in vitro therapeutic index than cisplatin against all the two cell lines (see the pictures of the color change of compounds during the MTT experiment in Fig. SI $6 \mathrm{~d}-\mathrm{f} \dagger$ ).

\subsection{Interaction of compounds with HSA using fluorescence spectroscopy}

3.5.1. Fluorescence quenching of HSA. Investigating the drug-protein interaction is one of the important factors in

Table 4 Quenching constants for the interaction of HSA with 1-6 complexes

\begin{tabular}{|c|c|c|c|c|c|c|c|}
\hline & $\mathrm{L}$ & 1 & 2 & 3 & 4 & 5 & 6 \\
\hline $\begin{array}{l}K_{\mathrm{SV}}\left(\times 10^{-5} \mathrm{M}^{-1}\right) \\
K_{\mathrm{q}}\left(\times 10^{-13} \mathrm{M}^{-1} \mathrm{~S}^{-1}\right) \pm \mathrm{SD}^{a}\end{array}$ & $1.79 \pm 0.02$ & $2.84 \pm 0.07$ & $4.17 \pm 0.009$ & $1.28 \pm 0.05$ & $1.89 \pm 0.03$ & $2.48 \pm 0.1$ & $1.74 \pm 0.02$ \\
\hline
\end{tabular}


Table 5 Values of $K_{\mathrm{a}}, n$ and $\Delta G\left(\mathrm{~kJ} \mathrm{~mol}^{-1}\right)$ parameters for systems of (compounds $\left.+\mathrm{HSA}\right)$ at $T=298 \mathrm{~K}$

\begin{tabular}{lllllll}
\hline & $\mathrm{L}$ & $\mathbf{1}$ & $\mathbf{2}$ & $\mathbf{3}$ & $\mathbf{4}$ & \multicolumn{1}{c}{$\mathbf{5}$} \\
$K_{\mathrm{a}}\left(\times 10^{-5} \mathrm{M}^{-1}\right) \pm \mathrm{SD}^{a}$ & $2.98 \pm 0.09$ & $1.76 \pm 0.1$ & $3.3 \pm 0.05$ & $0.8 \pm 0.06$ & $1.01 \pm 0.03$ & $3.4 \pm 0.1$ \\
$n$ & 1.34 & 1.29 & 1.29 & 1.25 & 1.2 & $1.8 \pm 0.07$ \\
$\Delta G$ & -41.6 & -41.3 & -42.8 & -39.4 & -40 & -4.3
\end{tabular}

${ }^{a}$ Data are presented as mean $\pm \mathrm{SD}$ (standard deviation). All experiments were independently performed three times.

achieving optimal therapeutic dose and awareness of drugprotein binding capacity. Since fluorescence spectroscopy is a powerful technique for studying the structure and properties of macromolecules in solution, this technique has been used to investigate the effect of synthetic compounds on human serum albumin. ${ }^{64}$ There are two link locations for aromatic compounds (in IIA and IIIA subdomains) on albumin. ${ }^{65,66}$ The three aromatic amino acids of phenylalanine, tyrosine, and tryptophan can absorb in the ultraviolet region of the electromagnetic spectrum and contribute to the intrinsic fluorescence of proteins. ${ }^{67}$ The dominant intrinsic fluorophore in proteins is tryptophan. Tryptophan is more important because of its high absorption coefficient. HSA has only one tryptophan residue, Trp-214. ${ }^{68,69}$ When HSA interacts with other molecules this may change the fluorescence of Trp-214 which is a common response to binding of drug-HSA. ${ }^{70}$ The excitation wavelength of $280 \mathrm{~nm}$ (due to the high relative absorption of aromatic tyrosine and tryptophan amino acids) and the emission wavelength of 290 to $500 \mathrm{~nm}$ for L and other complexes (Fig. SI $7 \mathrm{a}-\mathrm{f} \dagger$ ) were recorded. ${ }^{11}$

The L effects on the fluorescence intensity of HSA is shown in Fig. 3. With increasing concentration of $\mathrm{L}$ at $298 \mathrm{~K}$ there is a decrease in the fluorescence intensity of HSA. The results show that the L quenches the fluorescence peak of HSA significantly even before its concentrations become equal to that of HSA.

Fluorescence quenching is described by the Stern-Volmer equation: ${ }^{70}$

$$
\frac{F_{0}}{F}=1+K_{\mathrm{SV}}[\mathrm{Q}]=1+K_{\mathrm{q}} \tau_{0}[\mathrm{Q}]
$$

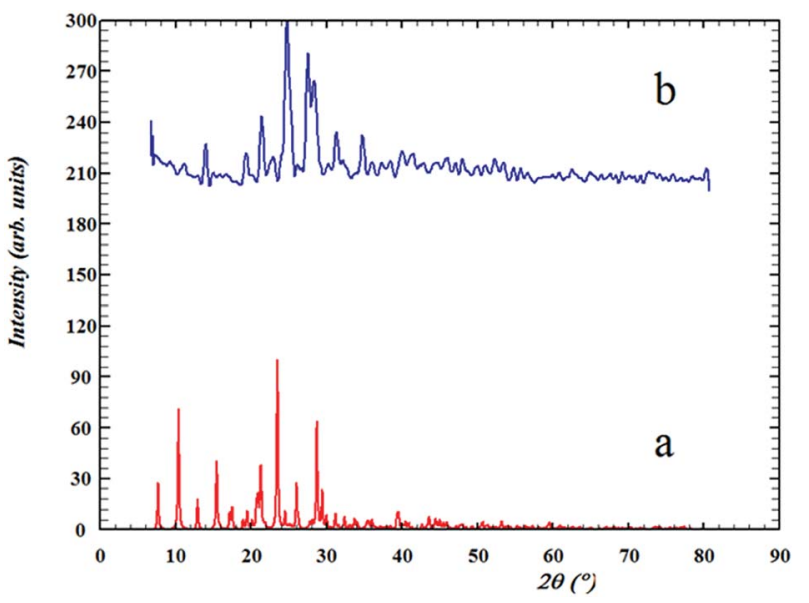

Fig. 5 The XRD patterns of (a) computed from single-crystal X-ray data of ligand $(\mathrm{L})$ and $(\mathrm{b})$ nanostructure of $L$ ligand. where $F_{0}$ and $F$ are the steady-state fluorescence intensities in the absence of a compounds and in its presence at [Q] concentration respectively. $K_{\mathrm{q}}$ is the quenching rate constant of the biomolecule, $\tau_{0}$ is the average lifetime of HSA without the quencher and its value is $10^{-8} \mathrm{~s}^{72}$ and $K_{\mathrm{Sv}}$ is the Stern-Volmer quenching constant.

Fluorescence quenching occurs by two mechanisms: dynamic and static quenching. Dynamic quenching is due to the collision of the quencher molecules with the desired protein, which reduces fluorescence and converts the energy into heat. Static quenching takes place by forming a complex of protein-quencher molecules. ${ }^{25}$ The formation of this complex produces a new species that has no emission in the range of the previous wavelength. In fact, dynamic quenching and static quenching are caused by diffusion and ground-state complex formation, respectively. ${ }^{73}$

The shape of the SV plot gives information on the quenching mechanism involved. The Stern-Volmer diagram is not linear and is curved (Fig. 4a), indicating that the quencher has created dynamic and static quenching (Fig. SI $7 \mathrm{~g}-1+$ ).

For the positive deviation cases a modified SV equation accounting for simultaneous static and dynamic mechanisms was used. For negative deviation cases the following equation was used:

$$
\frac{F_{0}}{F_{0}-F}=\frac{1}{f_{\mathrm{a}} K_{\mathrm{Sv}}} \frac{1}{[\mathrm{Q}]}+\frac{1}{f_{\mathrm{a}}}
$$

where $f_{\mathrm{a}}$ is the fraction of accessible fluorescence while the other parameters are as the same as those defined for classical Stern-Volmer equation (eqn (1)). ${ }^{74}$

The graph is linear (Fig. 4b) and from this one can get $f_{\mathrm{a}}$ and $K_{\mathrm{SV}}$. According to the literature, if $K_{\mathrm{q}}$ is more than $2 \times 10^{10} \mathrm{M}^{-1}$ $\mathrm{S}^{-1}$ this indicates that static quenching has a major role in quenching process and the role of dynamic quenching is almost insignificant (Fig. SI $\left.7 \mathrm{~m}-\mathrm{r}^{\dagger}\right){ }^{75}$ The $K_{\mathrm{SV}}$ values, calculated from eqn (2) for compounds 1-6 are collected in Table 4.

3.5.2. Binding and thermodynamic parameters, nature of binding forces. Binding parameters for a static quenching interaction are described by:

$$
\log \left(\frac{F_{0}-F}{F}\right)=\log K_{\mathrm{a}}+n \log [\mathrm{Q}]
$$

From the plot of $\log \left(\frac{F_{0}-F}{F}\right)$ versus $\log [\mathrm{Q}]$ (Fig. 4c), the number of binding sites $(n)$ and association constant $\left(K_{\mathrm{a}}\right)$ values were calculated for $\mathrm{L}$ ligand and complexes (Fig. SI 7s$\mathrm{x} \uparrow$ ) from the slope and the intercept on the $Y$-axis respectively (Table 5). ${ }^{76}$ 


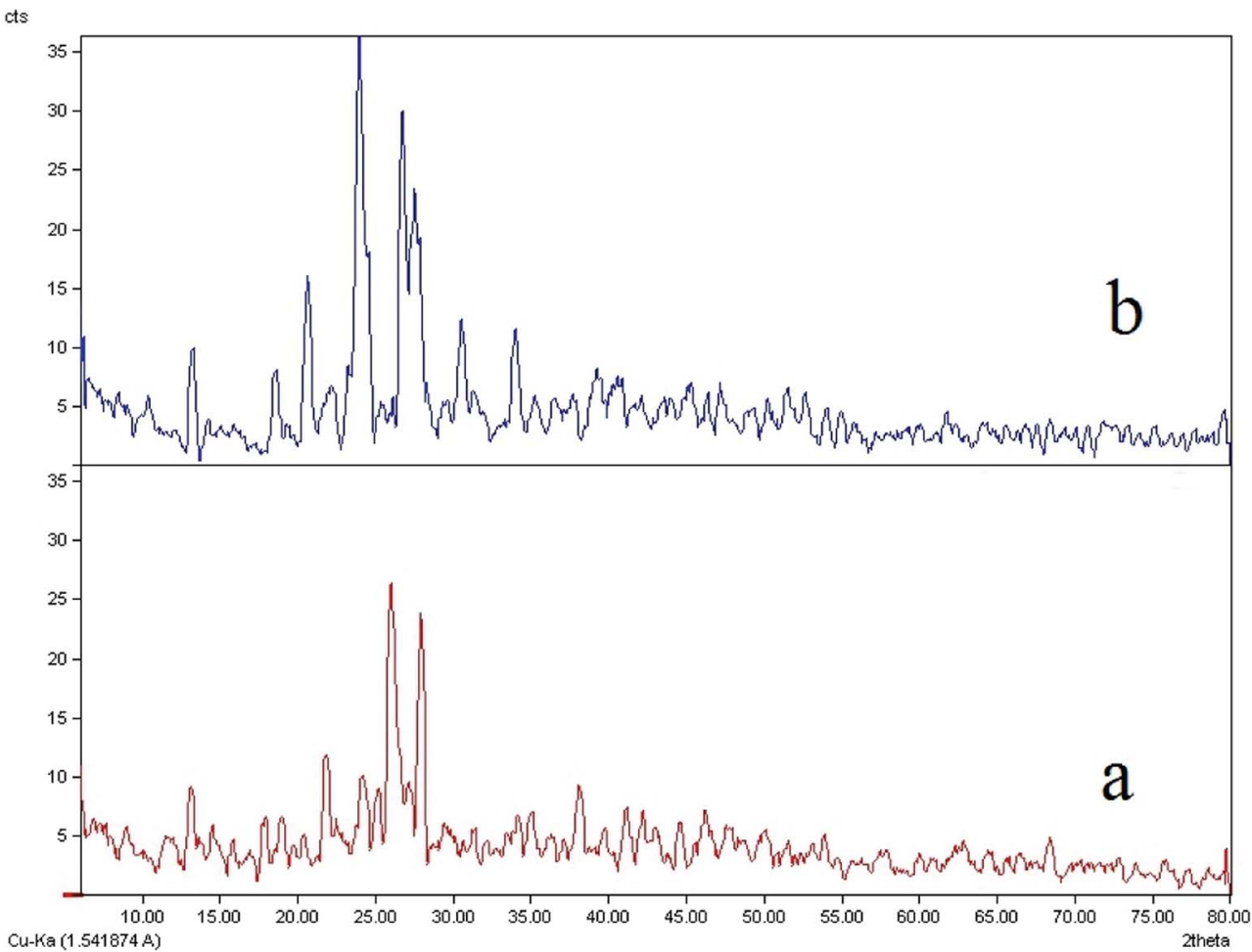

Fig. 6 The XRD patterns of (a) nanostructure of compound 2 and (b) nanostructure of the L ligand.

The thermodynamic parameters for reaction between a ligand and a protein are the main evidence for confirming the binding forces. The four types of non-covalent interactions include hydrogen bonds, van der Waals forces, electrostatic and hydrophobic bond interactions which play a key role in ligand binding to proteins. ${ }^{77}$ The value of the free energy change $(\Delta G)$ was calculated using van't Hoff equation (eqn (4))

$$
\Delta G=-R T \ln K_{\mathrm{a}}
$$

where $K_{\mathrm{a}}$ is the binding constant obtained from eqn (3) and $R$ is the universal gas constant and indicates the spontaneity of the binding process of peptide to human albumin. ${ }^{78}$

\subsection{Powder X-ray diffraction studies accompanied by SEM and TEM images}

Comparisons of the XRD patterns for the nanoparticulate materials obtained by the ultrasonic method show the experimental data are in good agreement with the simulated XRD patterns obtained from single crystal data which also confirm the phase purity of these compounds (Fig. SI $8 \mathrm{a}-\mathrm{d} \dagger$ ). The sharp bands of the samples indicate that the nanoparticles are well crystallized under these synthetic conditions and due to absence of a characteristic bar of impurities in the crystalline phase, the product is highly pure.

In Fig. 5b, it is clear that the bands 20, 22, 23, 26 and 27 have much higher intensity which is due to the crystallization

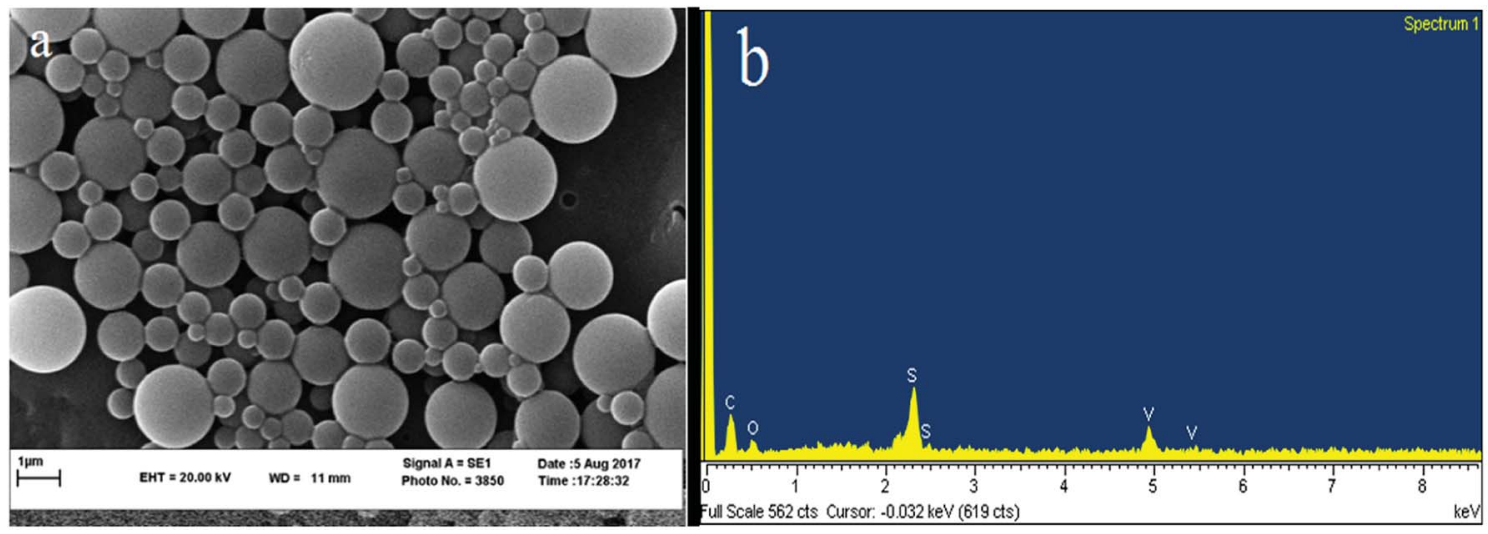

Fig. 7 (a) SEM image of complex 2, (b) EDX spectrum analysis of complex 2. 


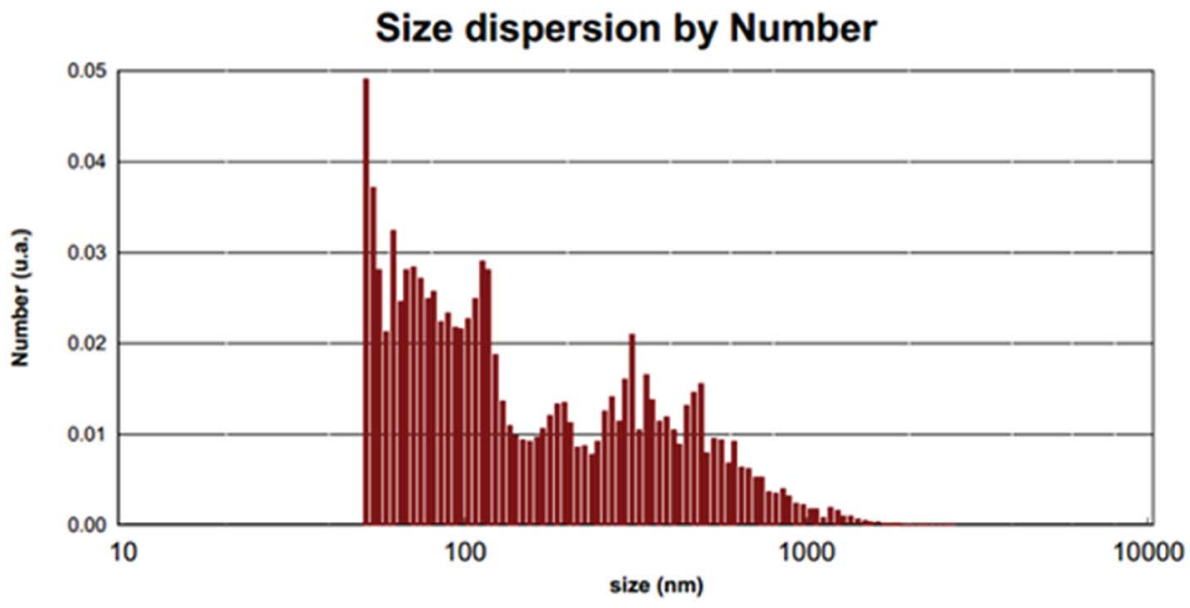

Fig. 8 The average nanoparticle size by PLS method.

method of the sample. The nanoparticle size is estimated by the Debye-Scherrer formula: ${ }^{79}$

$$
d_{\mathrm{RX}}=k \lambda / \beta \cos \theta
$$

where $d_{R X}$ is the crystallite size, $k=0.9$ is a correction factor to account for particle shapes, $\beta$ is the value of full width at halfmaximum intensity (FWHM), $\lambda$ is the wavelength of the $\mathrm{Cu}$ target (1.5406 $\AA$ ), and $\theta$ is the Bragg angle. The average nanoparticle size for these 5 bands is $90.3 \mathrm{~nm}$.

The XRD spectrum of the ligand is compared to the XRD spectrum of the complexes. Fig. 6 illustrates that in the complex spectrum of 2, some bands are removed or displaced regards to the ligand spectrum, indicating a reaction between the ligand and the metal. EDX analyses indicate that compound 2 is successfully obtained via the current synthetic route (Fig. 7b).

The average nanoparticle size for bands no. 21, 24, 25 and 27 is $90.4 \mathrm{~nm}$ by the Debye-Scherrer formula which is also confirmed by SEM images (Fig. 7a) and measurements based on PLS (Fig. 8). See SEM and TEM images, EDS analyses and PLS measurements for samples in SI $8 \mathrm{e}-\mathrm{o}$ Section. $\dagger$

\section{Conclusion}

In this work, we synthesized and characterized one novel $\mathrm{L}$ ligand and six metal complexes from the dithiocarbazate family. Structural analysis of compounds shows that the L ligand crystallizes as a dimer with S-S bond while in the complexation the $\mathrm{S}-\mathrm{S}$ bond of the ligand is broken and $\mathrm{L}^{\prime}$ is formed. $\mathrm{L}^{\prime}$ act as a tridentate ONS donor ligand. All the complexes are six coordinated with distorted octahedral configuration. These compounds are designed to be able to bind to HSA protein and to have anticancer properties. Studying the interaction of compounds with HSA using fluorescence spectroscopy reveals that with increasing concentration of compounds at $298 \mathrm{~K}$ the fluorescence intensity of HAS decreases and also these compounds quench the fluorescence peak of HSA significantly even before their concentrations become equal to that of HSA. $K_{\mathrm{SV}}$ values indicate that static quenching plays a major role in the quenching process and the role of dynamic quenching is almost insignificant. Moreover, the cellular toxicity of the compounds was tested against the Hela and MCF-7 cell lines. All compounds exhibit good cytotoxic activity when compared to the clinical drug, cisplatin. Even complexes 2 and $\mathbf{6}$ show better in vitro therapeutic index than cisplatin against Hela and MCF-7 cell lines. Furthermore, nanoparticles of the complexes are obtained by ultrasonic methods. XRD spectra of the samples confirm that the products are highly pure. The nanoparticle size is estimated by PLS analysis.

\section{Conflicts of interest}

There are no conflict to declare.

\section{Acknowledgements}

This work was supported by the Ferdowsi University of Mashhad (3/39699-1394/11/11) and Buali Research Institute. Authors thank Tulane University for support of the Tulane Crystallography Laboratory.

\section{References}

1 R. Takjoo, S. S. Hayatolgheibi and H. Amiri Rudbari, Inorg. Chim. Acta, 2016, 447, 52-58.

2 R. Centore, R. Takjoo, A. Capobianco and A. Peluso, Inorg. Chim. Acta, 2013, 404, 29-33.

3 M. Hakimi, K. Moeini, Z. Mardani and R. Takjoo, Phosphorus, Sulfur Silicon Relat. Elem., 2014, 189, 596-605.

4 T.-J. Khoo, M. K. b. Break, K. A. Crouse, M. I. M. Tahir, A. M. Ali, A. R. Cowley, D. J. Watkin and M. T. H. Tarafder, Inorg. Chim. Acta, 2014, 413, 68-76.

5 M. Eslami Moghadam, M. Saidifar, A. Divsalar, H. MansouriTorshizi, A. A. Saboury, H. Farhangian and M. Ghadamgahi, J. Biomol. Struct. Dyn., 2016, 34, 206-222.

6 Z. H. Siddik, Oncogene, 2003, 22, 7265-7279.

7 S. H. Lai, G. B. Jiang, J. H. Yao, W. Li, B. J. Han, C. Zhang, C. C. Zeng and Y. J. Liu, J. Inorg. Biochem., 2015, 152, 1-9.

8 M. Kudrat-E-Zahan and M. S. Islam, Russ. J. Gen. Chem., 2015, 85, 979-983. 
9 R. Takjoo, R. Centore, M. Hakimi, S. Ali Beyramabadi and A. Morsali, Inorg. Chim. Acta, 2011, 371, 36-41.

10 A. Alim, Sci. J. Chem., 2015, 3, 35.

11 A. Taha, A. A. Emara, M. M. Mashaly and O. M. Adly, Spectrochim. Acta, Part A, 2014, 130, 429-439.

12 M. R. Maurya, S. Dhaka and F. Avecilla, Polyhedron, 2014, 81, 154-167.

13 E. Zangrando, M. T. Islam, M. A.-A. A. A. Islam, M. C. Sheikh, M. T. H. Tarafder, R. Miyatake, R. Zahan and M. A. Hossain, Inorg. Chim. Acta, 2015, 427, 278-284.

14 S. Kundu, D. Mondal, K. Bhattacharya, A. Endo, D. Sanna, E. Garribba and M. Chaudhury, Inorg. Chem., 2015, 54, 6203-6215.

15 B.-K. Koo and U. Lee, Bull. Korean Chem. Soc., 2002, 23, 613616.

16 D.-W. KIM, U. LEE and B.-K. KOO, Bull. Korean Chem. Soc., 2004, 25, 1071-1074.

17 T. S. Morais, F. C. Santos, L. Corte-Real and M. H. Garcia, J. Inorg. Biochem., 2013, 129, 94-101.

18 A. Bijelic, S. Theiner, B. K. Keppler and A. Rompel, J. Med. Chem., 2016, 59, 5894-5903.

19 J. Toneatto and G. A. Arguello, J. Inorg. Biochem., 2011, 105, 645-651.

20 X. B. Fu, Z. H. Lin, H. F. Liu and X. Y. Le, Spectrochim. Acta, Part A, 2014, 122, 22-33.

21 T. Chatterjee, A. Pal, S. Dey, B. K. Chatterjee and P. Chakrabarti, PLoS One, 2012, 7, 37468.

22 Y. Wang, X. Wang, J. Wang, Y. Zhao, W. He and Z. Guo, Inorg. Chem., 2011, 50, 12661-12668.

23 N. Shahabadi, A. Khorshidi and N. H. Moghadam, Spectrochim. Acta, Part A, 2013, 114, 627-632.

24 Y. Gou, Y. Zhang, J. Qi, Z. Zhou, F. Yang and H. Liang, J. Inorg. Biochem., 2015, 144, 47-55.

25 F. Faridbod, M. R. Ganjali, B. Larijani, S. Riahi, A. A. Saboury, M. Hosseini, P. Norouzi and C. Pillip, Spectrochim. Acta, Part A, 2011, 78, 96-101.

26 Bruker, $A P E \times 3$ and $S A D A B S$, Bruker AXS Inc., Madison, Wisconsin, USA, 2016.

27 G. M. Sheldrick, Acta Crystallogr., Sect. A: Found. Adv., 2015, 71, 3-8.

28 G. M. Sheldrick, Acta Crystallogr., Sect. C: Struct. Chem., 2015, 71, 3-8.

29 K. Mohanan, R. Aswathy, L. P. Nitha, N. E. Mathews and B. S. Kumari, J. Rare Earths, 2014, 32, 379-388.

30 F. R. Pavan, P. I. d. S. Maia, S. R. A. Leite, V. M. Deflon, A. A. Batista, D. N. Sato, S. G. Franzblau and C. Q. F. Leite, Eur. J. Med. Chem., 2010, 45, 1898-1905.

31 H. L. Singh and A. K. Varshney, Bioinorg. Chem. Appl., 2006, 2006, 1-7.

32 L. Ronconi, C. Maccato, D. Barreca, R. Saini, M. Zancato and D. Fregona, Polyhedron, 2005, 24, 521-531.

33 Y. Zhang, X. Wang, W. Fang, X. Cai, F. Chu, X. Liao and J. Lu, Bioinorg. Chem. Appl., 2013, 2013, 437134.

34 N. R. Pramanik, M. Chakraborty, D. Biswal, S. S. Mandal, S. Ghosh, S. Chakrabarti, W. S. Sheldrick, M. G. Drew, T. K. Mondal and D. Sarkar, Polyhedron, 2015, 85, 196-207.
35 N. Gandhi, A. Kumar, C. Kumar, N. Mishra, P. Chaudhary, N. K. Kaushik and R. Singh, Main Group Chem., 2015, 15, 35-46.

36 J. U. Mondal, J. G. Zamora, M. D. Kinon and F. A. Schultz, Inorg. Chim. Acta, 2000, 309, 147-150.

37 C. Das, P. Adak, S. Mondal, R. Sekiya, R. Kuroda, S. I. Gorelsky and S. K. Chattopadhyay, Inorg. Chem., 2014, 53, 11426-11437.

38 A. Mathavan, A. Ramdass and S. Rajagopal, Transition Met. Chem., 2015, 40, 355-362.

39 K. Bhattacharya, M. Maity, S. M. T. Abtab, M. C. Majee and M. Chaudhury, Inorg. Chem., 2013, 52, 9597-9605.

40 S. Zaidi, A. K. Chaturvedi, N. Singh and D. Chaturvedi, Curr. Chem. Lett., 2017, 6, 143-150.

41 E. Zangrando, M. S. Begum, M. C. Sheikh, R. Miyatake, M. M. Hossain, M. M. Alam, M. A. Hasnat, M. A. Halim, S. Ahmed, M. N. Rahman and A. Ghosh, Arabian J. Chem., 2017, 10, 172-184.

42 D. A. Abdel-Latif, H. M. Youssef and Y. G. Abou El Reash, J. Mol. Liq., 2017, 241, 456-468.

43 M. Yazdanbakhsh and R. Takjoo, Struct. Chem., 2008, 19, 895-903.

44 R. Takjoo, R. Takjoo, M. Yazdanbakhsh, A. Aghaei kaju and Y. Chen, Chin. J. Chem., 2010, 28, 221-228.

45 M. Amirnasr, M. Bagheri, H. Farrokhpour, K. J. Schenk, K. Mereiter and P. C. Ford, Polyhedron, 2014, 71, 1-7.

46 A. Kumar, P. Chaudhary, R. Singh and N. Kaushik, Main Group Chem., 2016, 15, 163-178.

47 A. A. Alshaheri, M. I. M. Tahir, M. B. A. Rahman, T. B. S. A. Ravoof and T. A. Saleh, Chem. Eng. J., 2017, 327, 423-430.

48 N. Nanjundan, R. Narayanasamy, R. J. Butcher, J. P. Jasinski, K. Velmurugan, R. Nandhakumar, M. D. Balakumaran, P. T. Kalaichelvan and V. G. Gnanasoundari, Inorg. Chim. Acta, 2017, 455, 283-297.

49 S. A. Elsayed, A. M. Noufal and A. M. El-Hendawy, J. Mol. Struct., 2017, 1144, 120-128.

50 T. Ahmad, K. V. Ramanujachary, S. E. Lofland and A. K. Ganguli, J. Mater. Chem., 2004, 14, 3406-3410.

51 A. Bartyzel, J. Coord. Chem., 2013, 66, 4292-4303.

52 M.-J. Niu, D.-W. Sun, H.-H. Li, Z.-Q. Cao, S.-N. Wang and J.-M. Dou, J. Coord. Chem., 2014, 67, 81-95.

53 I. Dalle-Donne, D. Giustarini, R. Colombo, A. Milzani and R. Rossi, Free Radical Biol. Med., 2005, 38, 1501-1510.

54 N. R. Pramanik, S. Ghosh, T. K. Raychaudhuri, S. Chaudhuri, M. G. B. Drew and S. S. Mandal, J. Coord. Chem., 2007, 60, 2177-2190.

55 N. R. Pramanik, S. Ghosh, T. K. Raychaudhuri, S. Ray, R. J. Butcher and S. S. Mandal, Polyhedron, 2004, 23, 15951603.

56 S. K. Dutta, D. B. McConville, W. J. Youngs and M. Chaudhury, Inorg. Chem., 1997, 36, 2517-2522.

57 G. F. Sousa, C. C. Gatto, J. Ellena and J. D. Ardisson, J. Chem. Crystallogr., 2011, 41, 838-842.

58 R. Mukhopadhyay, S. Bhattacharjee, C. K. Pal, S. Karmakar and R. Bhattacharyya, J. Chem. Soc., Dalton Trans., 1997, 2267-2272. 
59 M. A. Ali, A. H. Mirza, M. H. S. A. Hamid, F. H. Bujang and P. V. Bernhardt, Polyhedron, 2004, 23, 2405-2412.

60 E. J. Gao, L. Wang, M. C. Zhu, L. Liu and W. Z. Zhang, Eur. J. Med. Chem., 2010, 45, 311-316.

61 Q. Mi, Y. Ma, X. Gao, R. Liu, P. Liu, Y. Mi, X. Fu and Q. Gao, J. Biomol. Struct. Dyn., 2016, 34, 2339-2350.

62 A. I. Matesanz, J. M. Pérez, P. Navarro, J. M. Moreno, E. Colacio and P. Souza, J. Inorg. Biochem., 1999, 76, 29-37.

63 S. Moradell, J. Lorenzo, A. Rovira, S. van Zutphen, F. X. Avilés, V. Moreno, R. de Llorens, M. A. Martinez, J. Reedijk and A. Llobet, J. Inorg. Biochem., 2004, 98, 19331946.

64 B. Valeur, Molecular Fluorescence Principles and Applications, Wiley-VCH Verlag GmbH, 2001, ISBNs: 3-527-29919-X (Hardcover); 3-527-60024-8 (Electronic).

65 L. Chen and X. Chen, J. Mol. Graphics Modell., 2012, 33, 3543.

66 K. Kaneko, V. T. Chuang, A. Minomo, K. Yamasaki, N. V. Bhagavan, T. Maruyama and M. Otagiri, IUBMB Life, 2011, 63, 277-285.

67 F. Kratz, J. Controlled Release, 2008, 132, 171-183.

68 G. Fanali, A. di Masi, V. Trezza, M. Marino, M. Fasano and P. Ascenzi, Mol. Aspects Med., 2012, 33, 209-290.

69 J. Ghuman, P. A. Zunszain, I. Petitpas, A. A. Bhattacharya, M. Otagiri and S. Curry, J. Mol. Biol., 2005, 353, 38-52.
70 U. Kragh-Hansen, Biochim. Biophys. Acta, 2013, 1830, 55355544.

71 S. Sugio, A. Kashima, S. Mochizuki, M. Noda and K. Kobayashi, Protein Eng., 1999, 12, 439-446.

72 B. Rastegari, H. R. Karbalaei-Heidari, R. Yousefi, S. Zeinali and M. Nabavizadeh, Bioorg. Med. Chem., 2016, 24, 15041512.

73 L. Tabrizi, P. McArdle, A. Erxleben and H. Chiniforoshan, Eur. J. Med. Chem., 2015, 103, 516-529.

74 L. Yan, X. Wang, Y. Wang, Y. Zhang, Y. Li and Z. Guo, J. Inorg. Biochem., 2012, 106, 46-51.

75 T. S. Morais, F. C. Santos, L. Corte-Real and M. H. Garcia, J. Inorg. Biochem., 2013, 129, 94-101.

76 I. Matei and M. Hillebrand, J. Pharm. Biomed. Anal., 2010, 51, 768-773.

77 M. Tabatabaee, M. Ghassemzadeh, A. R. Dehghan, H. R. Khavasi and M. M. Heravi, Acta Crystallogr., Sect. E: Struct. Rep. Online, 2006, 63, o42-043.

78 H. Liu, X. Shi, M. Xu, Z. Li, L. Huang, D. Bai and Z. Zeng, Eur. J. Med. Chem., 2011, 46, 1638-1647.

79 H. P. Klug and L. E. Alexander, X-Ray Diffraction Procedures: For Polycrystalline and Amorphous Materials, ed. Harold P. Klug and Leroy E. Alexander, Wiley-VCH, 2nd edn, p. 992. ISBN 0-471-49369-4, May 1974. 